\title{
The Genetics and Cytology of Certain Cereals
}

\section{Morphological and Cytelogical Studies on Triploid, Pentaploid and Hexaploid Avena Hybrids ${ }^{1)}$}

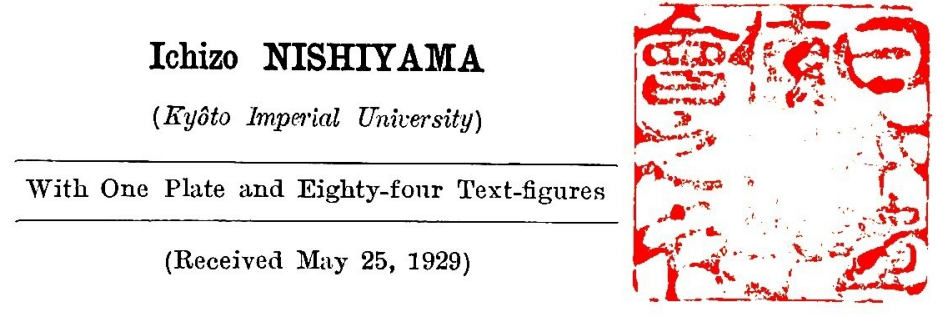

GONTEN'TS

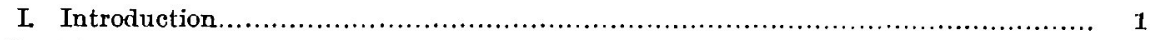

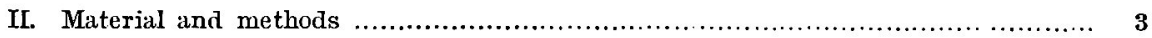

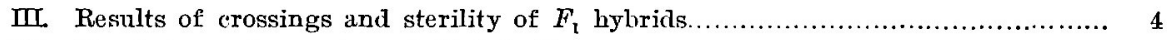

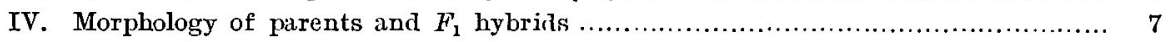

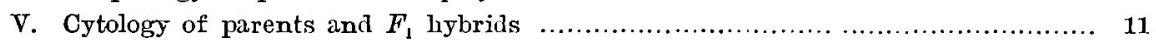

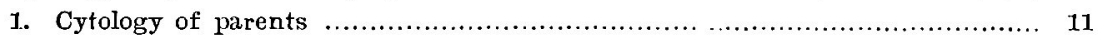

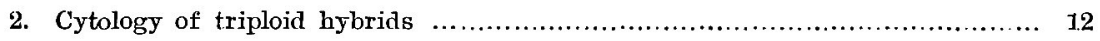

a. A. barba!a Potт $\times$ A. strigosa Schreb...................................... 1.2

$b$. The frequency of the number of litgging chromosomes ................ 19

3. Cytology of pentaploid hybrids ......................................... 23

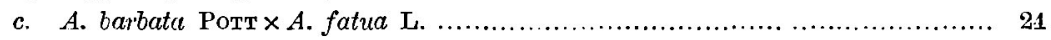

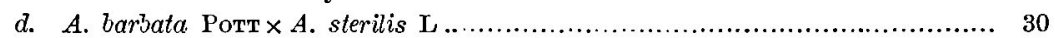

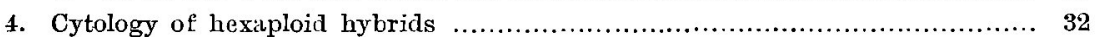

VI. Chromosome conjugation and nature of polyploidy in Avena ........................ 35

VII. Chromosome affinity among Avena species .................................. 42

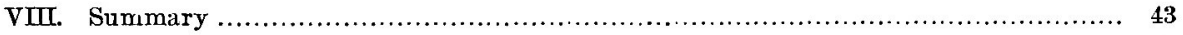

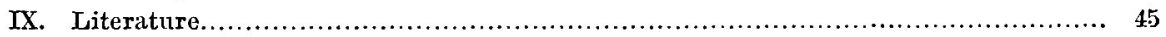

\section{Introduction}

It has been reported repeatedly that some cultivated forms in Avena may have arisen from different origins and among them many transition forms have been found in the region of their dispersion and in their native land. It is, therefore, a very interesting problem to study the domestication of the species in Avena. From the morpholo-

1) Contribution from the Laboratory of Genetics, Biological Institute, Kyôto Imperial University, Nc. 9. 
gical standpoint Ther.ung $\left(1919^{1)}, 1928\right)$ has already established a genealogical tree of Avena (Table 1).

Table 1. A genealogical tree of Avena established by Thellung.

\begin{tabular}{|c|c|c|c|c|c|}
\hline Naked oats & $\begin{array}{c}7 \\
\text { A. } n u d i b r e v i s \\
\uparrow \\
\end{array}$ & & A. $\stackrel{21}{\text { nuda }}$ & $?$ & \\
\hline $\begin{array}{l}\text { Cultivated } \\
\text { oats }\end{array}$ & $\begin{array}{c} \\
7 \\
\text { A. strigosa } \\
\text { (incl. var. brevis) } \\
\uparrow \\
\end{array}$ & $\begin{array}{c}14 \\
\text { A. abyssinica } \\
\uparrow \\
\uparrow\end{array}$ & $\begin{array}{c}1 \\
21 \\
\text { A. sativa } \\
\text { (incl. var. } \\
\text { orientalis) } \\
\uparrow \\
\end{array}$ & $\begin{array}{c}21 \\
\text { A. byzantina } \\
\uparrow \\
\uparrow\end{array}$ & $\begin{array}{c}\text { ? A. pserudo-sativa } \\
\uparrow\end{array}$ \\
\hline Wild oats & $\begin{array}{c}1 \\
14 \\
\text { A. barbata }\end{array}$ & $\begin{array}{c} \\
\text { A. Wiestii }\end{array}$ & $\begin{array}{c}1 \\
21 \\
\text { A. fatua }\end{array}$ & $\begin{array}{c}1 \\
21 \\
\text { A. sterilis }\end{array}$ & $\begin{array}{c}1 \\
21 \\
\text { A. Iudoviciana }\end{array}$ \\
\hline
\end{tabular}

The numbers are set down by the writer. They show haploid numbers of chromosomes found by KrHara (1919, 1921), GodLden (1925), Huskins (1927) etc.

It is quite remarkable that the results of various studies on Avena, morphological and plant geographical (TRABUT 1914), serological (ZADE 1914), cytological (KIHARA 1919, 1924, and others), hybridisation studies (Tschermak 1914) as well as investigations on immunity to infectious diseases (Vavilov 1914), have given the same phylogenetic relationship as Thellung's genealogical tree.

The present work arose from an attempt to ascertain the cytological behavior in interspecific hybrids of Avena. Not only does it elucidate the chromosome affinity between two species but also it will be of great value in solving the problem as to how the formation of the species in Avena has taken place in the course of their phylogenesis.

DoRsey (1924). has given an account of the cytology of pentaploid oat hybrids, but his observations differ from my own in some important points.

I have successfully obtained triploid, pentaploid and hexaploid oat hybrids. This paper chiefly deals with the chromosome behavior of $\mathrm{PM} \mathrm{C}$ in these hybrids and also hybrid sterility as well as observations on certain morphological characters.

1) After Thellung (1928). 


\section{Material and methods}

'The following species and interspecific hybrids are dealt with in this work.

Species :

$\begin{array}{ll}\text { Avena strigosa Schres. } & \text { A. barbata PoTr } \\ \text { A. fatua } L . & \text { A. sativa } L . \\ \text { A. sterilis } L . & \text { A. byzantina } \text { O. КосH. }\end{array}$

Hybrids :

A. barbata Potт $\times A$. strigosa Schnem.

" $\times A$. fatua L.

" $\times$ A. sterilis $\mathrm{L}$.

A. fatua L. $\times$ A. sativa L.

$\quad \quad \times$ A. sterilis $\mathbf{L}$.

A. sativa L. $\quad \times$ A. byzantina C. Косн.

A. sterilis L. $\times$,,

All crossings were carried out in the open field. I usually emasculated 10-15 spikelets per ear which would open one or two days later, and removed the remaining spikelets. Then such emasculated ears were enclosed in paraffined paper bags. After two days the stigmas of the mother plant were dusted with fresh spores of the pollen parent. Although the flowering time of oats is influenced by meteorological conditions, especially temperature, it takes place usually between 3 p.m. and 5 p.m. I observed, however, that the anthesis of A. strigosa and A. barbata were most intense at 7-8 p.m. and 9-10 p.m. respectively ${ }^{13}$. I could, therefore, safely perform castration in the fore-noon, and artificial pollination from 1 to 3 p.m.

For the count of the somatic chromosome number of the hybrid plant, root tips were fixed in Flemming's solution of Bonn-institute for 24 hours. To examine the maturation divisions in PMC, the best results were obtained by KinARA's fixing method (1924) using Flemming's solution after a few minutes treatments in CARnoy's fluid. Bouns's solution, chromo-acetic mixture and CARNOY's fluid were also used but did not give better results.

By the paraffin method all permanent preparations were made from the fixed material. Sections were cut $12-15 \mu$ thick, and stained with HeIdenhain's iron-alum hämatoxylin. BelLing's iron aceto-carmine

1) Dr. Misono has kindly informed me that A. barbata also blooms in the evening at Sapporo. 
method modified by STow (1927) gave also beautiful figures of chromosomes in PMC. This method was mainly employed to determine the stage in the meiosis of $\mathrm{PMC}$ after which we were able to fix only anthers containing actively dividing cells.

All figures of chromosomes were drawn with the aid of ABBE's camera lucida, and $Z_{\mathrm{kISs}} \frac{1}{12}$ objective and Huyghens ocular $15 \times$ are used. These figures are magnified about 2000 diameters but Figs. 34 and 65 about 400 diameters.

\section{Results of crossings and sterility of $F_{1}$ hybrids}

According to Tschermak (1914) hybridisations among A. fatua, $A$. sativa and $A$. sterilis easily succeeded and $F_{1}$ hybrids were completely fertile. VAviLov (1914) did not always succeed, in repeated crossings, in getting a hybrid between $A$. strigosa and $A$. sativa. Thellung (1928 P. 418) mentioned in the foot note the following: "zwischen $A$. strigosa und A. sativa fehlen dagegen $Z$ wischenformen völlig, nach $E$. v. T'schermak und nach SchegalofF (1920) gelingt nicht einmal künstliche Kreuzung." Kinara (1924) also failed to obtain a hybrid between $A$. barbata $(2 \mathrm{n}=28)$ and $A$. strigosa $(2 \mathrm{n}=14)$. Thus it is generally considered that oat hybrids between two species having different chromosome numbers are obtained with great difficulty. However during the last two years I have succeeded in getting various oat hybrids. The results of crossings and germination tests of $\mathrm{F}_{1}$ kernels produced as immediate results of crossings are given in Table 2.

From these results it will be shown that all interspecific hybrids, with a few exceptions, are easily obtained by artificial pollinations. Most of these $F_{1}$ kernels germinated and produced mature hybrid plants. But in both years (1927 and 1928) it failed to get a tetraploid hybrid between $A$. strigosa and four species, A. fatua, A. sativa, A. sterilis and $A$. byzantina, and two reciprocal hybrids. But if the stigmas of the mother plant in these crosses were pollinated the ovary grew during development to a size as large as that of a normal kernel, but at the time of harvest it was extremely shrivelled. None of these kernels germinated. The number of such incomplete kernels is shown within brackets in Table 2.

Some ears of $F_{1}$ plants and their parents were bagged to protect them against foreign pollen grains, while the others remained unprotected. The kernels obtained from these ears are described in Table 3. 
Table 2. Results of interspecific hybridisations.

\begin{tabular}{|c|c|c|c|c|c|c|}
\hline Crosees & Yeur & $\begin{array}{l}\text { No. of } \\
\text { ears } \\
\text { employed }\end{array}$ & $\begin{array}{l}\text { No. of } \\
\text { flowers } \\
\text { pollinated }\end{array}$ & $\begin{array}{c}\text { No. of } \\
\text { kernels } \\
\text { obtained }\end{array}$ & $\begin{array}{l}\text { No. of } \\
\text { kernels } \\
\text { sown }\end{array}$ & $\begin{array}{c}\text { No. of } \\
\text { kernels } \\
\text { germinated }\end{array}$ \\
\hline A. barbata $\times$ strigosa & 1927 & 5 & 56 & 7 & 5 & 5 \\
\hline$"$ & 1928 & 3 & 35 & 20 & 20 & 20 \\
\hline A. strigosa $\times$ fatua & 1927 & 3 & 32 & (11) & (11) & 0 \\
\hline & 1928 & 2 & 32 & (18) & ( 8$)$ & 0 \\
\hline A. strigosa $\times$ sterilis & 1927 & 4 & 37 & (17) & (17) & 0 \\
\hline " & 1928 & 4 & 52 & $(40)$ & (16) & 0 \\
\hline A. strigosa $\times$ satica & $"$ & 2 & 32 & (13) & (10) & 0 \\
\hline$\quad \quad \times$ byzantina & " & $\mathbf{3}$ & 45 & $(27)$ & (19) & 0 \\
\hline A. fatua $\times$ strigosa & 1927 & 6 & 75 & (4) & (4) & 0 \\
\hline A. sterilis $\times \quad$ ", & " & 4 & 49 & ( 2$)$ & ( 2$)$ & 0 \\
\hline A. barbata $\times$ fatua & ", & 4 & 42 & 11 & 11 & 11 \\
\hline$"$ & 1928 & 3 & 28 & 5 & 5 & 5 \\
\hline A. Uarbata $\times$ sterilis & 1927 & 3 & 33 & 16 & 16 & 13 \\
\hline , & 1928 & 3 & 27 & 8 & 8 & 7 \\
\hline A. barbata $\times$ saiviva & $"$ & 3 & 35 & 14 & 10 & 10 \\
\hline$" \quad \times$ byzantina & , & 3 & 27 & 10 & 9 & 9 \\
\hline A. fatua $\times$ sativa & 1927 & 2 & 20 & 13 & 13 & 12 \\
\hline "X ster $\cdot$ ilis & " & $\mathbf{2}$ & 23 & 3 & 3 & 3 \\
\hline A. sativa $\times$ byzantina & $"$ & 1 & 10 & 3 & 3 & 3 \\
\hline,$\quad \times$ sierilis & 1928 & 2 & 17 & 17 & 10 & 10 \\
\hline A. sterilis $\times$ sativa & , & 2 & 21 & 21 & 10 & 7 \\
\hline " $\quad \times$ byzantina & 1927 & 1. & 10 & 6 & 6 & 4 \\
\hline $\begin{array}{l}\text { A. byzantina } \times \text { fatua } \\
(\text { A. barbata } \times \text { strigos } a) \mathrm{F}_{1}\end{array}$ & 1928 & 1 & 10 & 9 & 9 & 7 \\
\hline $\begin{array}{l}\times \\
\text { A. strigosa } \\
\text { A. barbata }\end{array}$ & " & 6 & 88 & 2 & 2 & 2 \\
\hline $\begin{array}{l}\times \\
(\text { A. barbata } \times \text { strigosa }) \mathrm{F}_{1} \\
(\text { A. barbata } \times \text { fatua }) \mathrm{F}_{1}\end{array}$ & , & 3 & 24 & 1. & 1 & 1 \\
\hline $\begin{array}{c}\times \\
\text { A. barbata } \\
\text { (A. barbata } \times \text { fatua }) \quad \mathrm{F}_{1} \\
\times \\
\text { A. fatua }\end{array}$ & 1927 & 2 & 13 & 0 & 0 & 0 \\
\hline $\begin{array}{c}(A . \text { barbata } \times \text { sterilis }) \mathbf{F}_{1} \\
\times \\
\text { A. sterilis }\end{array}$ & 1928 & $\begin{array}{l}6 \\
8\end{array}$ & $\begin{array}{r}92 \\
110\end{array}$ & $\begin{array}{l}7 \\
0\end{array}$ & 7 & $\begin{array}{l}2 \\
0\end{array}$ \\
\hline
\end{tabular}

Whether or not a kernel is set in the third and higher florets of a spikelet may determine the genetic characteristics of the species, but this is much influenced by outer conditions, while the kermel production of the first and the second floret is almost independent of environmental conditions. It seems, therefore, botter to compare the fertility by the percentage of these kernels to all the first and second florets examined. 
Table 3. Fertility of $F_{1}$ hybrids and their parents.

\begin{tabular}{|c|c|c|c|c|c|c|c|c|}
\hline \multirow{2}{*}{$\begin{array}{l}\text { Pure species } \\
\text { and hybrids }\end{array}$} & \multicolumn{2}{|c|}{ No. of ears } & \multicolumn{2}{|c|}{ No. of florets } & \multicolumn{2}{|c|}{ No. of kernels } & \multicolumn{2}{|c|}{$\begin{array}{l}\text { Percentage } \\
\text { of kernels }\end{array}$} \\
\hline & Bagged & $\begin{array}{l}\text { Unpro- } \\
\text { tected }\end{array}$ & Bagged & $\begin{array}{l}\text { Unpro- } \\
\text { tected }\end{array}$ & Baggeal & $\begin{array}{l}\text { Unpro- } \\
\text { tected }\end{array}$ & Bagged & $\begin{array}{l}\text { Unpro- } \\
\text { tected }\end{array}$ \\
\hline A. strigosa & 12 & & 1408 & & 1405 & & 99.79 & \\
\hline A. barbata & 11 & & 1420 & & 1407 & & 99.08 & \\
\hline A. falua & 3.4 & & 1085 & & 1080 & & 99.54 & \\
\hline A. sativa & 20 & & 1781 & & 1771 & & 99.27 & \\
\hline A. sterilis & 15 & & 610 & & 608 & & 99.67 & \\
\hline A. byzantina & 20 & & 616 & & 615 & & 99.84 & \\
\hline A. barbata $\times$ strigosa & 14 & 15 & 2234 & 2470 & 7 & 30 & 0.31 & 1.21 \\
\hline$" \quad \times$ fatua & 18 & 35 & 2469 & 5486 & 6 & 169 & 0.24 & 3.08 \\
\hline$" \quad \times$ sterilis & 18 & 31 & 1268 & 2434 & 0 & 4 & 0.00 & 0.16 \\
\hline A. fatua $\times$ sativa & 17 & & 3032 & & 3013 & & 99.37 & \\
\hline " $\times$ sterilis & 20 & & 2246 & & 2240 & & 99.73 & \\
\hline A. sativa $\times$ byzantina & 17 & & 1158 & & 1156 & & 99.83 & \\
\hline A. sterilis $\times \quad$ " & 18 & & 880 & & 878 & & 99.77 & \\
\hline
\end{tabular}

It is rarely observed that a second floret of a spikelet is rudimentary. In such a case the second flower was omitted from the count. This method has been used in the present study.

All pure species show fertility as high as more than 99 per cent. by selfing. In the $F_{1}$ of $A$. barbata $\times$ strigosa 6 bagged ears out of 14 set 1 or 2 kernels, and 15 unprotected ears with one exception, setting none, produced 1 to 4 kernels per ear. In pentaploid hybrids many of the anthers did not usually dehisee but some opened and spread their pollen grains. Among 18 bagged ears of A. barbata $\times$ fatua only 4 resulted in 1 or 2 kernels, while 35 unbagged ears set 1 to 14 kernels. A. barbata $\times$ sterilis had 18 bagged ears, setting no kernel. A single kernel was obtained from each of 4 ears unprotected, the total number of those unbagged being 31 . In these hybrids a few kernels were set in the third florets but it is not discussed here. The kernel production is generally greater on the unbagged ears than on these bagged. It seems probable that on the one hand, this deviation may be due to natural crossings of unprotected ears and, on the other hand, unfaborable influences of bagging on setting kernels. Some kernels were obtained by pollinating $F_{1}$ plants with pollens of one parent, and in the reversal crossing (Table 2). As Tschermas (1914) has already observed, all 4 different hexaploid hybrids, A. fatua $\times$ sativa, A. fatua $\times$ sterilis, A. sterilis $\times$ byzantina, and A. sativa $\times$ byzantina, show fertility as high as their parents. 
In conclusion it may be said that the triploid and pentaploid oat hybrids under consideration are highly sterile but not completely, and that the hexaploid hybrids show complete fertility.

\section{Morphology of parents and $F_{1}$ hybrids}

Some remarkable characters of the parent and the $F_{1}$ hybrid are briefly described below. Lengths of awns, lemmas and empty glumes were measured with those of the first floret. Spikelets of all parent species and hybrids are shown in Plate I.

Avena strigosa Schreb.: Culms erect in early growth periods, averaging $122 \mathrm{~cm}$ long; nodes dark violet, glabrous; sheaths waxy; ears semi-unilateral, with 105 spikelets on an average; spikelets usually 2-flowered; basilar articulation of all florets solidified; basal hairs absent or few rudimentary hairs present; pedicels carry a slight pubescence only on the sides of their lips; empty glumes $16 \mathrm{~mm}$ long; lemmas yellowish gray to gray, glabrous, $19 \mathrm{~mm}$ long; awns twisted and geniculate, short (29 $\mathrm{mm}$ long).

A. barbata Pотт : Culms $127 \mathrm{~cm}$ long, spreading in early growth periods; nodes dark violet, glabrous; sheaths waxy; ears equilateral, wide spreading, drooping, with 64 spikelets; spikelets usually 2-flowered sometimes 3 ; basilar articulation of each floret evident; basal hairs present in bushy ring; pedicels hervily pubescent; empty glumes 23 $\mathrm{mm}$ long; lommas brown to dark brown, heavily Iubescent, $20 \mathrm{~mm}$ long; awns twisted and geniculate, $40 \mathrm{~mm}$ long.

A. fatua L.: Culms somi-erect in early growth periods, $127 \mathrm{~cm}$ long; nodes green, glabrous; sheaths slightly waxy; ear's equilateral, wide spreading, drooping, with 80 spikelets; spikelets usually 2 -flowered; basilar articulation distinct, all florets readily separating from their axes; basal hairs present in bushy ring, stiff, medium long; emply glumes $22 \mathrm{~mm}$ long; lemmas covered with long hairs; $17 \mathrm{~mm}$ long; awns twisted and geniculate, $38 \mathrm{~mm}$ long.

A. sativa L.: Culms semi-spreading in early growth periods, $91 \mathrm{~cm}$ long; nodes, sheaths and ears similar to those of A. fatua except that the number of spikelets is less, namely 45 ; spikelets 2-flowered seldom 3 ; basilar articulations of florets solidified; basal hairs wanting or occasionally a few hairs present at the lateral sides of the base of the first floret; pedicels glabrous; empty glumes $29 \mathrm{~mm}$ long; lemmas glabrous, yellow to yellowish gray, $19 \mathrm{~mm}$ long; awns present only on the first floret, but often wanting, slightly twisted and straight or slightly 
geniculate, $43 \mathrm{~mm}$ long.

A. sterilis L.: Culms semi-erect in early growth periods, $108 \mathrm{~cm}$ long; nodes glabrous, green; sheaths slightly waxy; ears equilateral, remarkable drooping, with about 21 spikelets; spikelets usually 4-flowered, seldom 5 in which case there is always sterility; basilar articulation of the first floret distinct and the others persist strictly to their pedicels; basal hairs present on the first floret, stiff, long; pedicels of the first florets short, strong, pubescent, persist to the second florets; empty glumes 47 $\mathrm{mm}$ long; lemmas dark brown, covered with thick, long and stiff hairs, $40 \mathrm{~mm}$ long; awns present on both the first and second florets, remarkably twisted and geniculate, very long (95 mm).

A. byzantina C. Косн.: Culms semi-spreading in early growth periods $87 \mathrm{~cm}$ long; nodes green, numerous short hairs present below the nodes and a few above them; sheaths waxy; ears equilateral, very drooping, with small number of spikelets, namely 15 ; spikelets usually 4-flowered, but the fourth flowers are always sterile; basilar articulation, basal hairs, pedicels, and awns nearly similar to those of $A$. sterilis except that the length of awns is $71 \mathrm{~mm}$ long; empty glumes $39 \mathrm{~mm}$ long; lemmas light black, carrying a few long hairs, $29 \mathrm{~mm}$ long.

A. barbata Ротт $\times A$. strigosa Schreb.: Culms spreading in early growth periods, longer than those of either parent, $135 \mathrm{~cm}$ long; nodes dark violet, glabrous; sheaths waxy; type of ears intermediate, with 84 spikelets; spikelets 2-3-flowered; basilar articulation distinct, all florets separate easily from their axes as in $A$. barbata; basal hairs present in bushy ring; pedicels have heavy pubescence; empty glumes intermediate long $(19 \mathrm{~mm})$; lemmas dark brown, with long and stiff hairs, longer than those of either parent $(21 \mathrm{~mm}$; awns twisted and geniculate, intermediate long $(39 \mathrm{~mm})$ but rather resemble that of $A$. barbata.

A. barbata PoтT $\times A$. fatua L.: Culms spreading or semi-spreading in early growth periods, $143 \mathrm{~cm}$ long, longer than those of either parent; nodes are intermediately dark violet in color, glabrous; sheaths waxy; ears equilateral, wide spreading, slightly drooping, with 76 spikelets; spikelets usually 2-flowered, seldom 3 ; basilar articulation evident; basal hairs present, thick, long; pedicels heavily pubescent; empty glumes 23-24 mm loug; lemmas heavily pubescent, $19 \mathrm{~mm}$ long; awns twisted and geniculate, $42 \mathrm{~mm}$ long, larger than those of either parent.

A. barbata Pотт $\times A$. sterilis L.: Culms spreading or semi-spreading in early growth periods, $131 \mathrm{~cm}$ long, showing hybrid vigor; nodes are slightly dark violet in color, glabrous; sheaths waxy; ears equilateral, drooping, with 38 spikelets; spikelets usually 3 -flowered, seldom 4 in 
which case they are rudimentary; basilar articulation of the first florets evident, the others fixed on their pedicels as in A. sterilis; basal hairs present, thick, stiff, long; pedicels of the first florets heavily pubescent, but those of the second florets glabrous; empty glumes $35 \mathrm{~mm}$ long; lemmas brown to dark brown, thick pubèscent, $33 \mathrm{~mm}$ long; awns twisted and geniculate, $73 \mathrm{~mm}$ long.

A. fatua L. $\times$ A. sativa L.: Culms semi-spreading in early growth periods, $112 \mathrm{~cm}$ long; nodes green, glabrous; sheaths slightly waxy; ears equilateral, slightly drooping, wide spreading, with 90 spikelets, being more than those of either parent; spikelets 2-flowered; basilar articulation solidified as in $A$. sativa; a few long basal hairs present on the lateral sides of the base of the first floret; pedicels of the first florets carry a few pubescence, their hairs very short; empty glumes $25 \mathrm{~mm}$ long; lemmas brown to dark brown, intermediately pubescent only on the first floret, $17 \mathrm{~mm}$ long; awns present only on the first florets, twisted and geniculate, $42 \mathrm{~mm}$ long.

A. fatua L. $\times A$. sterilis L. : Culms semi-spreading in early growth periods, $119 \mathrm{~cm}$ long; nodes grcen, glabrous; sheaths slightly waxy; ears equilateral, drooping, with 56 spikelets; spikelets usually 3-flowered; basilar articulation of the first florets remarkable, the other florets persist to their pedicels as in A. sterilis; basal hairs of the first florets present, thick; empty glumes $33 \mathrm{~mm}$ long; lemmas dark brown, heavily pubescent, $25 \mathrm{~mm}$ long; awns twisted and geniculate, $65 \mathrm{~mm}$ long.

A. sativa L. $\times$ A. byzantina C. Косн. : Culms semi-spreading in early growth periods, $90 \mathrm{~cm}$ long; nodes green, short hairs present above and below the nodes; sheaths waxy but intermediate; ears equilateral, wide spreading, very drooping, with 34 spikelets; spikelets $2-3$-flowered, usually 3; basilar articulation of all florets solidified; a few basal hairs present on the lateral sides of bases of the first florets, stiff, long; pedicels glahrous; empty glumes $35 \mathrm{~mm}$ long; lemmas of the first florets carry one or two long hairs, light black, $25 \mathrm{~mm}$ long; awns present on the first florets, twisted and geniculate, $64 \mathrm{~mm}$ long.

A. sterilis L. $\times A$. byzantina C. KocH. : Culms semi-spreading in early growth periods, $98 \mathrm{~cm}$ long; nodes green, short hairs present below the nodes; sheaths intermediately waxy; ears equilateral, wide spreading, very drooping, with 24 spikelets, being more than those of either parent; spikelets usually 4-flowered; basilar articulation of the first florets evident, the second and higher florets are fixed on their axes ; basal hairs present, thick, stiff, long; pedicels of the first florets heavily pubescent, empty glumes $42 \mathrm{~mm}$ long; lemmas very pubescent, brown to dark brown, 34 
$\mathrm{mm}$ long; awns twisted and geniculate, $83 \mathrm{~mm}$ long.

Taking several characters described above, the following conclusion is given.

Culms: In the triploid and pentaploid hybrids the length of culms is longer than that of either parent, and in the remaining hybrids exactly intermediate. The spreading character in early growth periods is incompletely dominant to semi-spreading or erect but in the triploid hybrid its dominancy is almost complete.

Color; During early growing periods nodes of $A$. strigosa and $A$. barbata are colored dark violet, but after the time of ripening the color becomes lighter and lighter. Nodes of $F_{1}$ plants between these species and others having green nodes are dark violet in color but distinctly lighter than the parent. Brown to dark brown color of lemmas is dominant to yellow and light black. Light black is dominant to yellow. In triploid and pentaploid hybrids lemmas and hairs of the florets which set no kernel are light brown in color, but those of a fertile flower are properly colored, brown to dark brown.

Wax: The waxy character of the sheath is partially dominant to the slightly waxy or non-waxy character.

Basilar articulation: Although the degree of solidification of bases differs, in general, it may be said that the non-disarticulation is dominant.

Hairs: Hairiness on various parts of the second florets is recessive to smoothness, while in the first florets the reverse is true though intermediate. But some exceptions appear, for instance, at the dorsal side of the base of the first floret no pubescence is dominant. The hybrid between $A$. fatua and $A$. sativa has a very few short hairs on the pedicel of the first floret but $A$. sativa $\times$ byzantina has nothing.

Awns: A. sativa used in my present study has a weak awn only on the first floret or occasionally none at all. $\mathrm{F}_{1}$ plants between $A$. sativa and other species with two or more awns show a medium awn on the first floret, but on the other florets lack any trace of awns. In the length of awns hybrids also show a blend of two parents.

The other characters: Lengths of lemmas, empty glumes, and the number of spikelets per ear are generally intermediate between two parents.

The above mentioned genetic behaviors of certain characters of oat hybrids are largely in agreement with those observed by earlier authors, Nilsson-Ehle (1911), Tschermar (1914), Surface (1916) Meurman (1926) etc., while it is of great interest in this connection that in the hybrid, $A$. barbata $\times$ strigosa, smoothness and non-disarticulation of both 
florets which are dominant or incompletely dominant in all other cases are converted to be recessive.

\section{Cytology of parents and $F_{1}$ hybrids}

Investigations were carried out upon the chromosome behavior at the maturation divisions of $\mathrm{PMC}$, and upon tetrad as well as microspore formations in various interspecific oat hybrids, but I will here omit the observations on the stages preceding metaphase and consider only chromosomal conditions after that stage.

Before examining the chromosome hehavior of hybrids it is important to study the cytological features of the pure species. First of all, therefore, we begin to observe the meiosis of parents.

\section{Cytology of parents}

The first division: A number of Avena species have been studied and the following chromosome numbers have been counted in $\mathrm{PMC}$. A. strigosa has 7 haploid chromosomes; $A$. barbata $14 ; A$. fatua, $A$. sativa, A. sterilis and A. byzantina have 21 (Figs. 1-4).
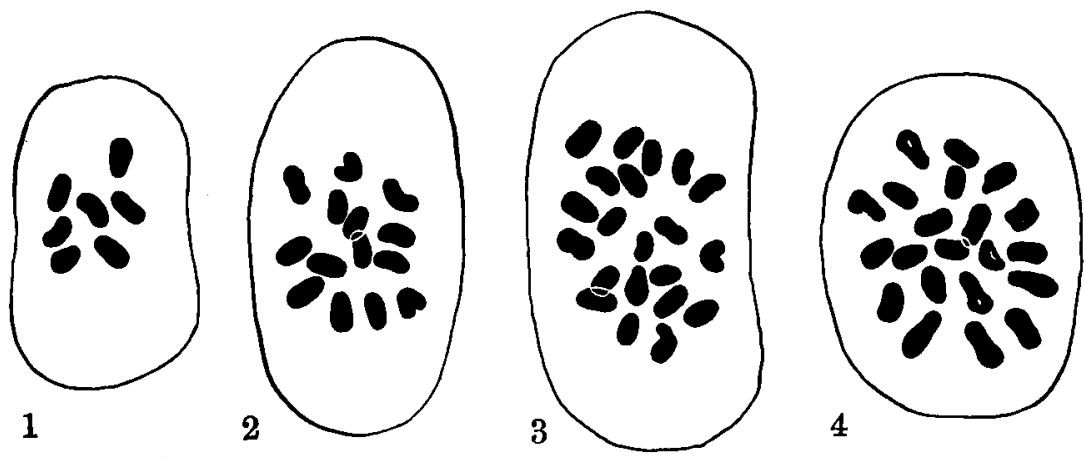

Figs. 1-4. The first division metaphase of PMC of parent species.

$\begin{array}{lll}\text { Fig. 1. A. strigosa ScHREB. } & \mathrm{n}=7 \\ \text { Fig. 2. A. barbata Potr } & \mathrm{n}=14 \\ \text { Fig. 3. } & \text { A. sterilis L. } & \mathrm{n}=\mathbf{2 1} \\ \text { Fig. 4. } & \text { A. fatua L. } & \mathrm{n}=\mathbf{2 1}\end{array}$

These numbers were first reported by Kinara (1919, I924) and repeatedly confirmed from observaions by GouLdEN (1925), Huskins (1927) and others. Bivalents are always formed in a haploid number and no remarkable difference in shape and size is recognisable among them. 
All bivalents divide almost simultaneously in the anaphase, and the divided halves move to opposite poles in a regular manner. Two daughter nuclei enter the interkinesis condition.

The second division: All chromosomes are regularly arranged on the equatorial plane in the metaphase of the second division, and in the anaphase each of the longitudinal halves of chromosomes passes to the spindle poles. The members of the pollen tetrad, and pollen grains are uniform in shape and size.

In all species the maturation divisions are quite regular, and no significant irregularities have been found.

\section{Cytology of triploid hybrids}

\section{a. A. barbata Pотт $\times$ A. strigosa SchReв.}

Somatic chromosomes: In this hybrid 14 chromosomes from $A$. barbata and 7 from A. strigosa are contributed so that 21 chromosomes

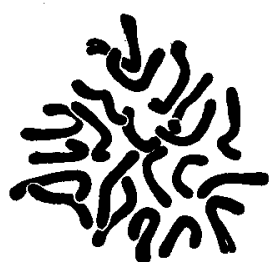

Fig. 5.

A. barbata $\times$ strigosa Somitic nuclear plate showing 21 chromosomes. would be expected as a somatic number. This was actually confirmed in root tip cells of $F_{1}$ plants (Fig. 5). These somatic chromosomes are slender and size differences among them are slightly observed.

The first division: At the first maturation division of this hybrid 7-9 bivalents are observed. Among them $0-3$ bivalents can mate the third homologous chromosomes out of univalents, forming trivalents. The frequency of the number of bivalents and trivalonts found in 100 dividing pollen mother-cells is given in Table 4.

Table 4. Frequency of the number of bivalents and trivalents found in $A$. barbata $\times$ strigosa. Count made at the metaphase as shown in Figs. 6-11.

\begin{tabular}{c|rrr|r}
\hline III II+III & 7 & 8 & 9 & Total \\
\hline 0 & 38 & 17 & 2 & 57 \\
1. & 24 & 6 & & 30 \\
2 & 9 & 2 & & 11 \\
3 & 2 & & & 2 \\
\hline Total & 73 & 25 & 2 & 100
\end{tabular}

For the sake of convenience, trivalents will be treated at present as bivalents. Then PMC with 7 bivalents are observed most frequently, 
73 per cent., 25 per cent. of those with 8 bivalents are found and only 2 per cent. of the same with 9 bivalents. PMC without trivalents are also shown in 57 per cent. and the rest, 43 per cent., have one or more trivalents. Univalent chromosomes vary from 3 to 7 , depending on the number of bivalents and trivalents.

The association of two components of bivalents is nearly as close as in the parents. In the side view trivalents show a V- or Y-shape and the proportion of $\mathrm{V}$ to $\mathrm{Y}$ is found to be $47: 11$ in an actual number (Figs. 7, 8, 9 and 11). Unmated univalents are long and slender, and are more or less curved. Occasionally one arm of a single univalent is much elongated. The univalent appears to be conjugated to a point of a bivalent, but it may not be noted as a true conjugation (Figs. 6 and 8). Throughout the observation four cases showed a tetrapartite chromosome, probably not a tetravalent, representing a $\mathrm{N}$-configuration (Fig. 10). Four elements of this complex are arranged in a zigzag and alternately go to opposite poles as in certain Oenotheras (Cleland 1923, 1924, 1926; Håxansson 1926, 1928 ; KinARA 1927 and Sinotô 1927).

At earlier stages of the metaphase of the first division all bivalents and trivalents, if present, make a normal equatorial plate. Univalents, however, are more or less scattered throughout the cell (Figs. 6, 8, 9 and 10). Before bivalents divide, all univalents arrange themselves at the metaphase plate of bivalents in strikingly regular fashion (Fig. 11). In a few cases some univalents are still found at some distance from that plate. This behavior especially resembles that of the canina roses reported by Täcкноцм (1922). In the next stage bivalents have completed their division and are moving apart on their way to the poles. Two components of a trivalent chromosome go to the same pole and the rest to the other.

At the anaphase all divided halves of bivalents, and univalents show usually homotypic splits (Fig. 12). As shown in Fig. 13 split halves of univalents separate actually and move to different poles. But in some cases split halves fail to separate and both of them lying side by side are distributed by chance to either of two poles. Thr first division is, therefore, a combination of the reduction and the equation division.

Chromosomes lagging in the cytoplasm are frequently observed in the telophase. They are either monad or dyad chromosomes but in some cases it is difficult to distinguish them. The monad may be regarded as the separated half of a univalent and the dyad as an entire univalent (Figs. 14-17). Most of the lagging chromosomes arrive at 

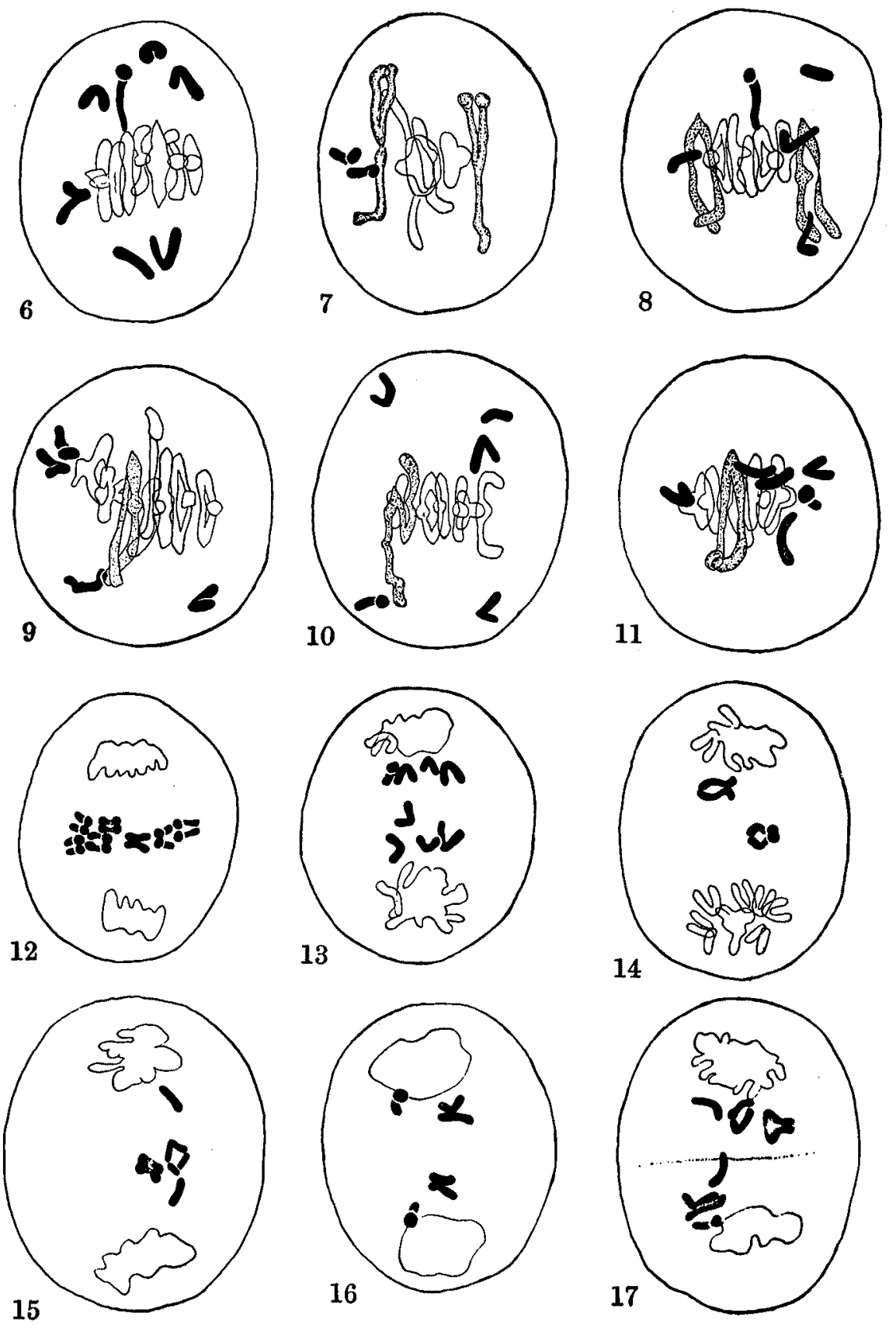

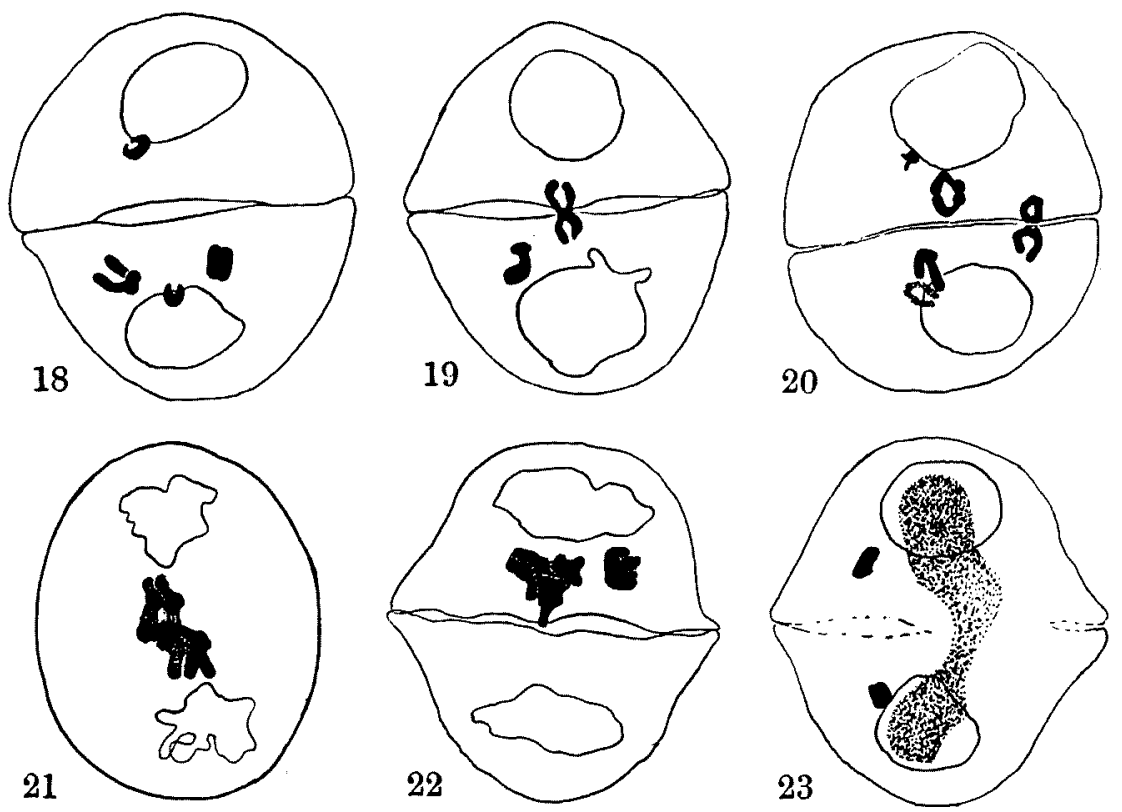

Figs. 6-23. The first maturation division of PMC of the $\mathbf{F}_{1}$ hybrid between $A$. barbata and $A$. strigosa.

Fig. 6. Side riew of metaphase showing $7_{\mathrm{II}}+7_{\mathrm{I}}$.

Fig. 7. One section of PMC showing especially 2 Y-trivalents.

Fig. 8. 2III $+5 \mathrm{II}+5 \mathrm{I}$. Trivalents show the V-shape.

Fig. 9. $1_{\text {III }}+7_{\text {II }}+4_{\text {I }}$.

Fig. 10. 1 tetrapartite chromosome $+6{ }_{I I}+5 \mathrm{I}$.

Fig. 11. Late metaphase. All chromosomes are arranged at the equatorial plate.

$1_{\text {III }}+6$ II +6 I .

Fig. 12. Late anaphase. 7 nnivalents, split equationally, are lagging at the equator.

Fig. 13. Split halves of 4 univalents are proceeding to opposite poles.

Fig. 14. Two dyads are lagging in the central portion of the cell. Longitudinal split is clearly seen.

Fig. 15. 2 dyads and 2 monads are lagging in the cytoplusm.

Fig. 16. Telophase. The sume as the above.

Fig. 17. 3 dyads and 3 monads are lost in the eytoplasm. Cytokinesis is carrying on.

Fig. 18. Interkinesis. 2 dyads and 2 monads are lost outside daughter nuclei.

Fig. 19. 1 lost dyad is cutting by the cell walls.

Fig. 20. 2 chromatic bodies and 3 dyads are seen. Among them 1 dyad has been cot off by the cell walls.

Fig. 21. Telophase. Some univalents fuse to a large chromatic clump.

Fig. 22. Interkinesis. 2 chromosome clumps have been enclosed into one daughter cell.

Fig. 23. The same stage showing 2 lagging chromosomes and a chromosome clump bridged between two daughter cells. 
or near the pole where a new nucleus is just formed, but occasionally some are lost in the cytoplasm (Fig. 18). Figs. 19 and 20 show a lagging chromosome at the central region which is cutting or cut off by cell walls of daughter cells. It is sometimes observed that all or most univalents are fused to one or two large chromosome masses at the telophase of the first division (Fig. 21). These chromosome masses are later enclosed in either of two daughter cells by cytokinesis (Fig. 22), but sometimes these masses are bridged between two daughter nuclei (Fig. 23). During the interkinesis the lost chromosomes or chromosome masses form additional micro-nuclei.

The second division: At the metaphase of the second division many figures show very regular plates, but there appear occasionally aberrant chromosomes, monads and dyads, lying outside the equatorial plate (Figs. 24-26). Two metaphase plates of daughter cells shown in Fig. 27 have 1 monad plus 7 dyads, and 1 monad plus 13 dyads respectively. In other cases chromosome distributions at the second division metaphase are observed as follows: $(9 \mathrm{D}+4 \mathrm{M})-(8 \mathrm{D}+4 \mathrm{M})$, $(9 \mathrm{D}+2 \mathrm{M})-(8 \mathrm{D}+$ aberrant $2 \mathrm{D}+2 \mathrm{M}),(9 \mathrm{D})-(11 \mathrm{D}+2 \mathrm{M}),(11 \mathrm{D})-(10 \mathrm{D})$ etc. $\mathrm{D}$ represents a dyad chromosome, and $\mathrm{M}$ a monad chromosome. Higher numbers of monads are not quite so frequent, and usually lower than those of univalents at the metaphase of the first division. This corresponds to the fact that at the anaphase of the first division some univalents were included in daughter nuclei without longitudinal splitting. This point we shali later discuss in detail.

In the succeeding stage a great number of chromosomes forming the second division plate divide longitudinally and pass to opposite poles, while a few undivided remain behind and subsequently to be distributed at random to the poles. The former may be dyads and the latter monads. Aberrant chromosomes near the pole can not take part in this division, as shown in Fig. 28. A lagging monad is so constricted that it may be mistaken for two connecting chromosomes (Fig. 29). Most of the lagging chromosomes are monads, but a few are apparently dyads which may have been left outside the metaphase plate in the second division. In Fig. 30 one daughter cell has 2 monads left at the equator, while the other has 2 monads and 1 dyad beginning to divide longitudinally. Occasionally univalents divide neither at the first nor at the second maturation division and they showing double nature are lost in the cytoplasm of tetrad cells (Fig. 33). In the present case some lagging chromosomes often fail to reach the poles and are left out of the reformed daughter nuclei. As in the first division most lagging 

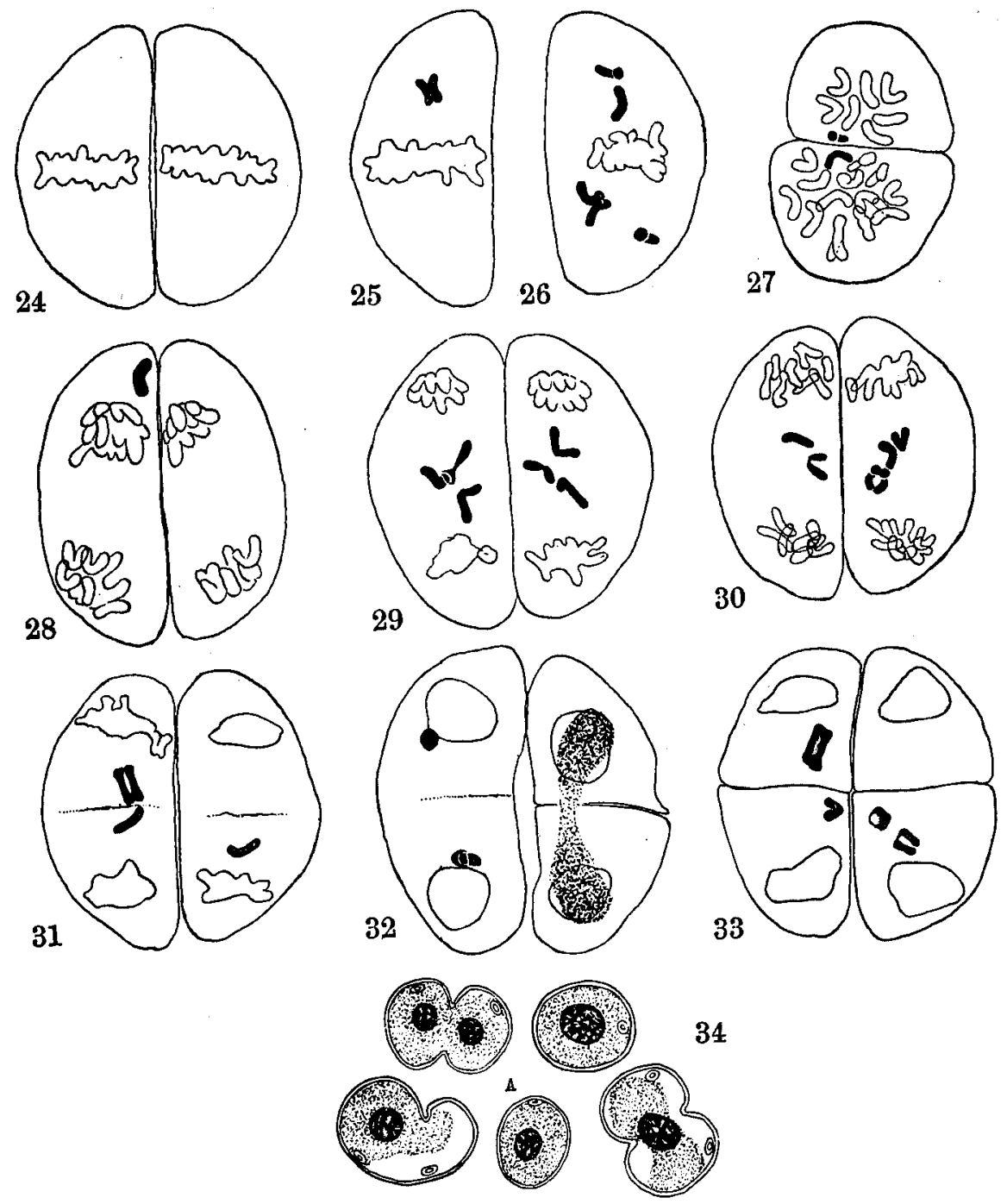

Figs. 21-33. The second maturation division of $\mathrm{PMC}$ of the $\mathrm{F}_{1}$ between $A$. larbata and $A$. strigosa.

Fig. 24. Side view of metaphise of the second division without aberrant chromosomes.

Fig. 25. The same with 1 aberrant dyit chromosome.

Fig. 26. 1 dydd and 3 monarls are laid ontside the division plate.

Fig. 27. Polar view of the same. The ppper cell has $7 \mathrm{D}+1 \mathrm{M}$ and the lower 13D+1M.

Fig. 28. An anaphasic cell showing 1 monad lying it the pole.

Fig. 29. Anaphase. Both daughter cells have 3 lagging monads. Some of them are renuarkably constricted. 
Fig. 30. A daughter cell (left) has 2 lagging monads and the other (right) 2 monads and 1 dyad beginning to split longitudinally.

Fig. 31. Telophase, 1 dyad and 2 monads are lagging.

Fig. 32. The cell (right) shows a chromatic clump extended hetween two reformed nuclei. The other (left) has 3 spherical chromatic bodies in the cytoplasm.

Fig. 33. A pollen tetrad with loet ohromosomes.

Fig. 34. Giant, twin and normal (marked A) pollen grains.

chromosomes unite sometimes with each other and become chromosome masses lying in the central portion of the cell or they extend between two poles (Fig. 32). Although both divisions are very irregular the resultant tetrad generally contains four cells. Cells of a pollen tetrad have usually some chromatic bodies in addition to a main nucleus.

Most of the young microspores are normal in shape and size, but occasionally they show abnormal appearances. The pollen marked $\mathrm{A}$ in Fig. 34 is the one found most frequently. Giant and twin microspores sometimes result as shown in the same figure. If both the nuclear division and cytokinesis remain incomplete a twin microspore has only one large nucleus. No matter how nuclear division is complete or incomplete, a twin microspore has a normal germ pore on each component. It is well known from what has been above stated that chromosome contents in the microspore differ owing to irregular meiotic divisions. Hence many pollen grains in the ripe anthers are almost empty or contain a scanty substance. Some of these, however, may be functional as it can be recognized by the low fertility of the bagged $F_{1}$ plant.

The analogous chromosome behavior is found in many hybrids of creals, for example, in various species hybrids of Triticum by KHHARA (1924), Thompson (1926 b) as well as Melburn and Thompson (1927), in Triticum vulgare $\times$ Secale by Krнara (1924) and Thompson (1926 a) and in the $\mathrm{F}_{1}$ of Aegilops-Triticum hybrids by Percival (1926) and KaGawa (1928). According to our observations (KIHARA and Nishiyama 1928) in the chromosome behavior especially with respect to chromosome binding, a remarkable similarity between Triticum and Avena hybrids is perceivable.

In conclusion the chromosome behavior during the meiosis of the triploid oat hybrid displays wide variability. The Pilosella type (RosenBERG 1917) and the Triticum type (KIHARA 1924) are prevalent, but they are somewhat combined with the Papaver type (LuUngdaHL 1924) which will be discussed later. In rare cases, as the random distribution of whole univalent elements takes place for all of them at the first 
division anaphase the Drosera type ${ }^{1)}$ must also be added to the types above given.

\section{b. The frequency of the number of lagging chromosomes.}

The number of univalent chromosomes rising at the first division metaphase may indirectly be counted from Table 4. The result is shown in Table 5. Table 5 also shows the number of lagging univalents observed at the anaphase as shown in Fig. 12. From these counts it is clear that lagging univalents are fewer than those found at the metaphase, by 26.54 per cent. This fact may be understood owing to the observation that univalents lying near a pole go to the same pole accompanied by the halves of normal bivalents and are not left at the equator.

The frequency of loss of dyads with which they have been lost at the interkinesis is also given in Table 5. According to this count about one third of lagging univalents fail to divide and are left out of daughter nuclei. At the same stage a number of counts of monads and dyads were carried out on 100 daughte: cells (Table 6). From this table it is clear that there is evidently no mutual relation between laggings of monads and dyads.

At the metaphase of the second division it is difficult to distinguish all monads from dyads at a side view because they are very small in size and monads are frequently arranged in the division plate, but chromosomes lying at some distance from the plate are clearly observed. Aberrant dyads scattered in the cytoplasm are markedly fewer in number than those at the interkinesis stage. This may be accounted for by the assumption that lost chromosomes existing near a daughter nucleus are included in the second division spindle when the nuclear membrane dissolves in the prophase. Re-included dyads take part in the subsequent division and behave in the same way as the halves of normal bivalents. Hence, both of them can not be distinguished from each other by their behavior or from morphological point of view. While the number of monads found here differs little from that at the interkinesis. Thus, at the formation of the second division plate, there is no evident tendency of re-inclusion of lost monads.

Aberrant dyads probably arrange themselves at the equatorial plate of the second division in the early anaphase. Most of them may at

1) After KrHARA (1924). 
once complete their lougitudinal splitting and pass to the poles, because, as shown in Table 8, lagging dyads are found to be much rarer than those at the previous stage. Split halves of these lagging dyads may sometimes be left near the equitor though such a case is very rare. In this stage, therefore, these halves may join with ordinary monads. However it is beyoud doubt that the great increase of lagging monads does not depend upon the addition of these secondary monads.

A count has bron made of loss of chromosomes at the telophase, the stage in Fig. 31 (Table 9). Table 10 also shows a count made at the tetrad stage (Fig. 33). From these results it is evident that as the process of the division progresses the number of re-inclusion of lagging chromosomes increases more and more.

Table 5. Frequencies of the number of lagging univalents.

\begin{tabular}{l|cccccccc|c}
\hline No. of lagging chromosomes & 0 & 1 & 2 & 3 & 4 & 5 & 6 & 7 & Total \\
\hline $\begin{array}{l}\text { Metilphase of the first division } \\
\text { Anaphase }\end{array}$ & & & & 4 & 8 & 26 & 24 & 38 & 100 \\
$\begin{array}{l}\text { Interkinesis. (Count milde of } \\
\text { lost dyads in both daughter } \\
\text { cells produced from a P M C.) }\end{array}$ & 23 & 26 & 34 & 11 & 4 & 2 & & & 100 \\
\hline
\end{tabular}

Table 6. Chromosome loss at iuterkinesis. Count made at about the stage shown in Fig. 18.

\begin{tabular}{r|rrrr|r}
\hline M & 0 & 1 & 2 & 3 & Total \\
\hline 0 & 19 & 21 & 4 & 1 & 45 \\
1 & 22 & 14 & & & 36 \\
2 & 13 & 2 & & & 15 \\
3 & 2 & 1 & & & 3 \\
4 & 1 & & & & 1 \\
\hline Tot.ll & 57 & 33 & 4 & 1 & 100
\end{tabular}


Table 7. Aberrant chromosomes at metaphase of the second division. Count made at the stage shown in Figs. 24-26.

\begin{tabular}{c|rrrrr|r}
\hline $\mathrm{D}$ & 0 & 1 & 2 & 3 & 4 & Total \\
\hline 0 & 37 & 18 & 9 & 1 & 1 & 66 \\
1 & 17 & 9 & 1 & 1 & & 28 \\
2 & 2 & 3 & 1 & & & 6 \\
\hline Totil & 56 & 30 & 11 & 2 & 1 & 100
\end{tabular}

Table 8. Lagging chromosomes at anaphase of the second division. Count made at about the stage shown in Figs. 29-30.

\begin{tabular}{|c|c|c|c|c|c|c|c|c|}
\hline D & 0 & 1 & 2 & 3 & 4 & 5 & c & Total \\
\hline 0 & 4 & 22 & 29 & 24 & 9 & 1 & 1 & 90 \\
\hline 1 & 2 & 2 & 3 & 1 & & & & 8 \\
\hline 2 & & 1 & & 1 & & & & 2 \\
\hline 'Total & 6 & 25 & 32 & 20 & 9 & 1 & 1 & 100 \\
\hline
\end{tabular}

Table 9. Chromosome loss at telophase of the second division. Count made at the stage as shown in Fig. 31.

\begin{tabular}{|c|c|c|c|c|c|c|}
\hline $\mathrm{D}$ & 0 & 1 & 2 & 3 & 4 & Total \\
\hline 0 & 14 & 37 & 28 & 12 & 1 & 92 \\
\hline 1 & 2 & 4 & 2 & & & 8 \\
\hline Total & 10 & 41 & 30 & 12 & 1 & 100 \\
\hline
\end{tabular}

Table 10. Frequency of chromosome loss at the tetrad stage. Count made at the stage shown in Fig. 33.

\begin{tabular}{c|rrrrr|c}
\hline M & 0 & 1 & 2 & 3 & 4 & Total \\
\hline 0 & 21 & 36 & 27 & 8 & 2 & 97 \\
1. & & 2 & 1 & & & 3 \\
\hline Tot:a1 & 24 & 38 & 28 & 8 & 2 & 100
\end{tabular}


Data of laggings of monad chromosomes mentioned above are again shown in frequency ploygons (Fig. 35). The polygons showing the data at the metaphase and the anaphase of the first division represent, of course, frequencies of the number of lagging univalents. In Fig. 36 frequencies of loss of dyads chromosomes are also shown. In this case the number of lagging dyads is the sum of those found in the daughter cells produced from one and the same mother cell. From these frequency polygons we can at a glance perceive the mode of the change of the number of lagging chromosomes during the meiosis of PMC.

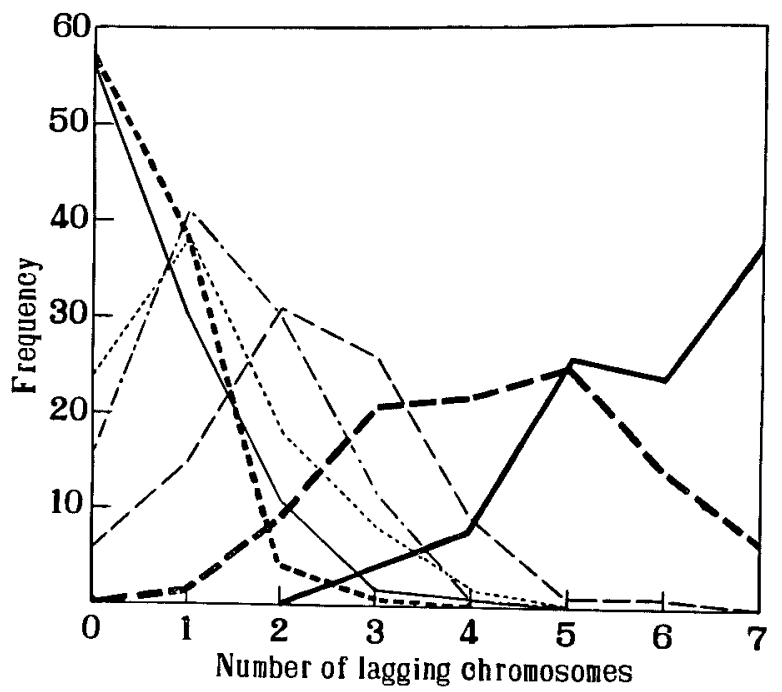

Fig. 35. Treqnency polygons of the number of lagging monad chromosomes during the meiosis of the $\mathrm{F}_{1}$ from A. barbata $\times$ strigosa.

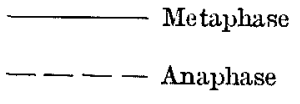

$$
\begin{aligned}
& -\cdots+- \text { Telophase } \\
& \text { Interkinesis (or tetrad stage } \\
& \text { at the second division) }
\end{aligned}
$$

Heavy lines show frequency polygons obtained at the first division and light lines those obtained at the second division.

WATKINs (1924) worked out mathematically and experimentally in great detail the behavior of univalents during the meiosis of PMC of 31- and 38-chromosome plants segregated from pentaploid whent hybrids. He (1925) further found that the chromosome loss occurs approximately with the same frequency in megaspore formation as in microspore formation. He also concluded that the loss of univalents happens quite at random. My own observations on the behavior of lagging univalents 


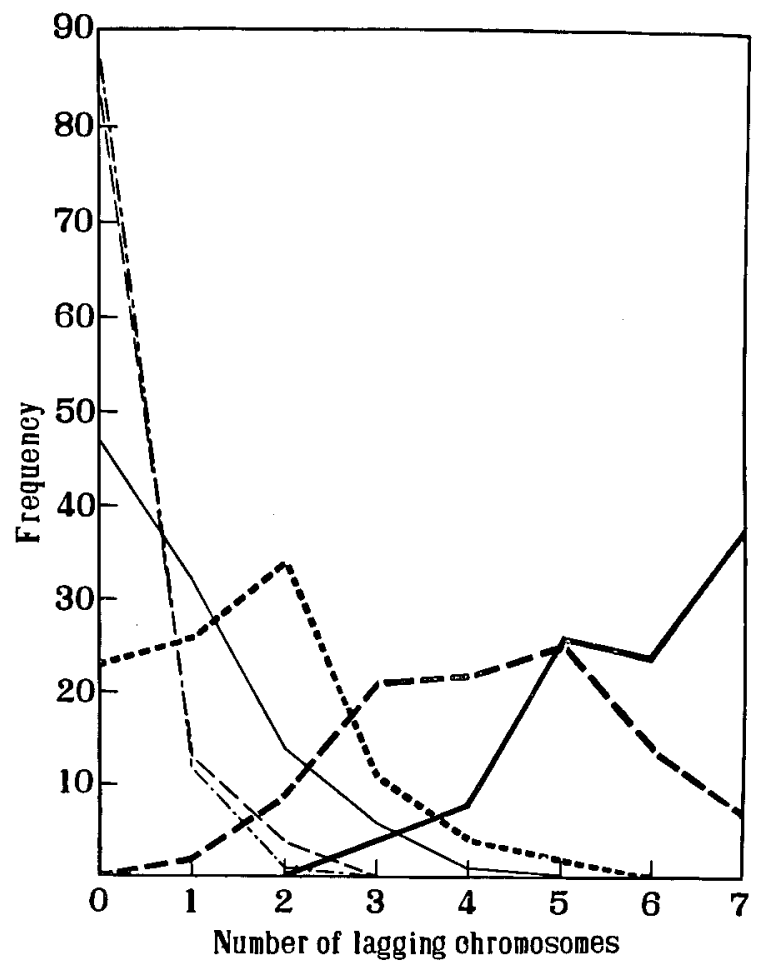

Fig. 36. Frequencies of the number of lagging dynd chromosomes during the meiosis of the $\mathrm{F}_{1}$ from $A$. barbata $\times$ strigosa. Lines show the same as in Fig. 3..

are, on the whole, agreement with those mentioned by Watkins, but differ in certain details. KAGAWA (1928) observed on the $F_{1}$ hybrid of I riticum vulgare, Komaba No. $3 \times$ Aegilops cylindrica that in most cases dyad and monad chromosomes are left in the cytoplasm at the anaphase and the telophase of both maturation divisions, but dyads are rarely lost at the second division.

\section{Cytology of pentaploid hybrids}

At the season of 1926 crosses, A. barbata $\times$ fatua and A. barbata $X$ sterilis, were made by the writer and only 1 kemel was obtained from each cross. In the next year $11 \mathrm{~F}_{1}$ seeds resulted in the former and 16 in the latter. Most of them gave nature hybrid plants in the summer of 1928. They were used by the writer for the present cytological investigations. 


\section{c. A. barbata Ротт $\times$ A. fatua L.}

Somatic chromosomes: Somatic chromosomes of the $F_{1}$ plant are slender, more or less curved and vary a little in size. Their number was clearly counted as 35 of which 14 might have been brought from A. barbata and 21 from $A$. fatua (Fig. 37).

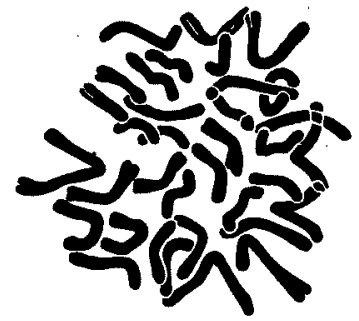

Fig. 37. Somatic chromosomes $(2 \mathrm{n}=35)$ of the $\mathrm{F}_{1}$ between $A$. barbata and $A$. fatua.

The first division: Principal features of chromosome behaviors in the meiosis of $\mathrm{PMC}$ are quite the same as that of the triploid hybrid. At the metaphase 2-11 bivalents inclusive of trivalents appear, 5-7 being of most frequent occurrence. $0-4$ trivalents were also observed and $\mathrm{V}$ - as well as $\mathrm{Y}$-shaped arrangements were found in the ratio of $135: 36$. A tetrapartite chromosome as shown in Fig. 46 is rarely observed.

The count of bivalents and trivalents was made in 100 dividing pollen mother-cells (Table $11 \mathrm{a}$ and $\mathrm{b}$ ). The number of bivalents was

Table 11. a. Frequencies of the number of bivalents and trivalents in $A$. barbata $\times$ fatua in 1927 . Count made at the first division metaphase as in Figs. 38-44.

\begin{tabular}{c|rrrrrrrrrr|r}
\hline III II+ III & 2 & 3 & 4 & 5 & 6 & 7 & 8 & 9 & 10 & 11 & Total \\
\hline 0 & & 2 & 3 & 12 & 7 & 8 & 4 & 1 & & & 37 \\
1 & 1 & & 3 & 9 & 10 & 8 & 4 & 1 & & 1 & 37 \\
2 & & & 4 & 5 & 5 & 4 & 3 & & 1 & & 22 \\
3 & & & 1 & 1 & 2 & & & & & & 4 \\
4 & & & & & & & & & & & 0 \\
\hline Total & 1 & 2 & 11 & 27 & 24 & 20 & 11 & 2 & 1 & 1 & 100
\end{tabular}

b. The same in 1928 .

\begin{tabular}{c|rrrrrrrrr|r}
\hline III II & 3 & 4 & 5 & 6 & 7 & 8 & 9 & 10 & 11 & Total \\
\hline 0 & & & 5 & 11 & 10 & 7 & 2 & 1 & & 36 \\
1 & 2 & 3 & 6 & 6 & 11 & 10 & 4 & 1 & 1 & 44 \\
2 & & & 1 & 4 & 8 & 1 & 1 & & & 15 \\
3 & & & & 1 & 2 & 1 & & & & 4 \\
4 & & & 1 & & & & & & & 1. \\
\hline Total & 2 & 3 & 13 & 22 & 31 & 19 & 7 & 2 & 1 & 100
\end{tabular}


somewhat fewer in 1927 than in 1928 , the mean value being $5.98 \pm$ 0.147 in the former and $6.78 \pm 0.145$ in the latter. The difference between the means, however, is not significant.

I observed only one case where no chromosome mating took place; 13 univalents were scattered throughout the cell and the others were beautifully arranged at the equator.

Two components of a bivalent always mate loosely with each other. They are almost always attached only at one end (Figs. 38-44). At the early metaphase bivalents and trivalents, if present, are arranged on the equatorial plate but univalents are irregularly scattered in the cytoplasm (Figs. 38-43). In the succeeding stage most univalents move to the equator and arrange themselves arround bivalents. Fig. 44 shows that 8 bivalents and 18 univalents are found on the division plate, and only 1 univalent lies at a distance. A polar view of such a figure is given in Fig. 45.

Univalents remain still at that plate after divided halves of bivalents have moved apart to the spindle poles (Fig. 47). Homotypic splits of univalents appear at the anaphase or in some cases at more or less earlier periods of the first division. Every lagging univalent divides equationally and the halves almost invariably go to opposite poles, though occasionally two halves lying side by side are seen to move to one pole (Fig. 48). As in the triploid oat hybrid some univalents may join to the group of divided halves of bivalents passing to the pole, for the number of lagging univalents is smaller than expected. At the telophase 4 groups of chromosomes are often found; the outer two are the groups composed of divided halves of bivalents and the inner two those of split halves of univalents which will soon reach the poles and are included in the former (Fig. 49). Many of the daughter nucleus, therefore, represent irregular outlines (Fig. 51). Observations on the early interkinesis show that a small number of monads are lost, in most cases $0-1$. Lost dyads are to be seen very rarely.

The second division: The second division plate is regular compared with that of the first division. The plate usually includes the majority of ehromosomes but some are apart. (Fig. 53). Fig. 54 shows very irregular plates which were sometimes found. In this case monads and dyads scattered in the whole cell are clearly seen. The number of chromosomes outside the division plate is usually $3-5$, distinctly more numerous than that of chromosomes lost at the telophase in the first division. It may be stated that monads included in daughter nuclei 

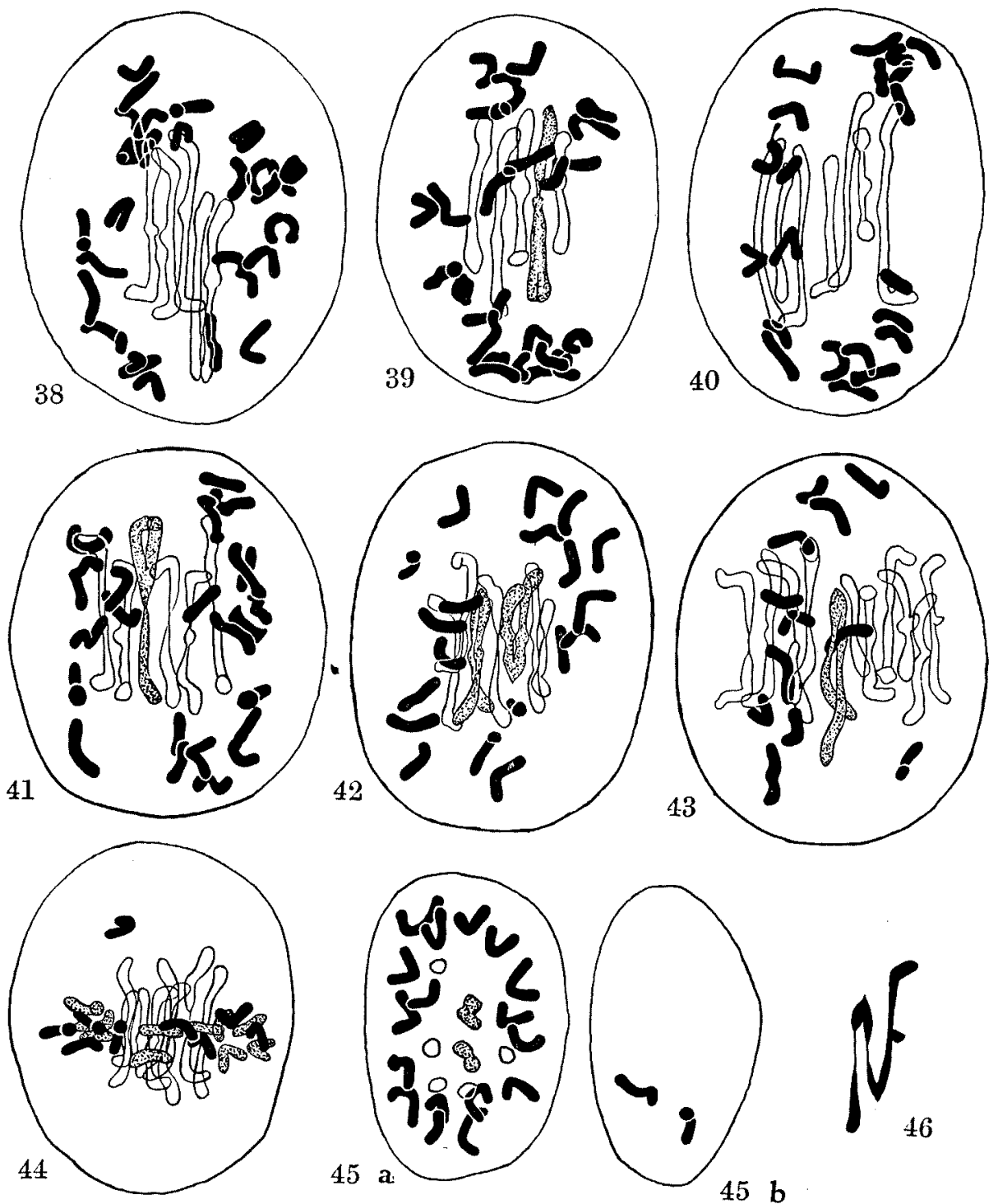

Figs. 33-59. The first maturation division of $1 \mathrm{MO}$ of $(A$, barbata $\times$ fatua $) \mathrm{F}_{1}$.

Fjg. 38. Sile view. $5 \mathrm{II}+25_{\mathrm{r}}$. Some univalente show alearly longitudinal splits.

Fig. 39. $1_{\mathrm{III}}+4 \mathrm{II}+24_{\mathrm{I}}$.

Fig. 40. $7 \mathrm{rI}+21 \mathrm{r}$.

Fig. 41. $1_{I I I}+5 I+22_{I}$, 1 trivalent represents the Y-shape.

Fig. 12. 2 III $+5 \mathrm{II}+19 \mathrm{I}$. Both trivalents show the V-shape. 

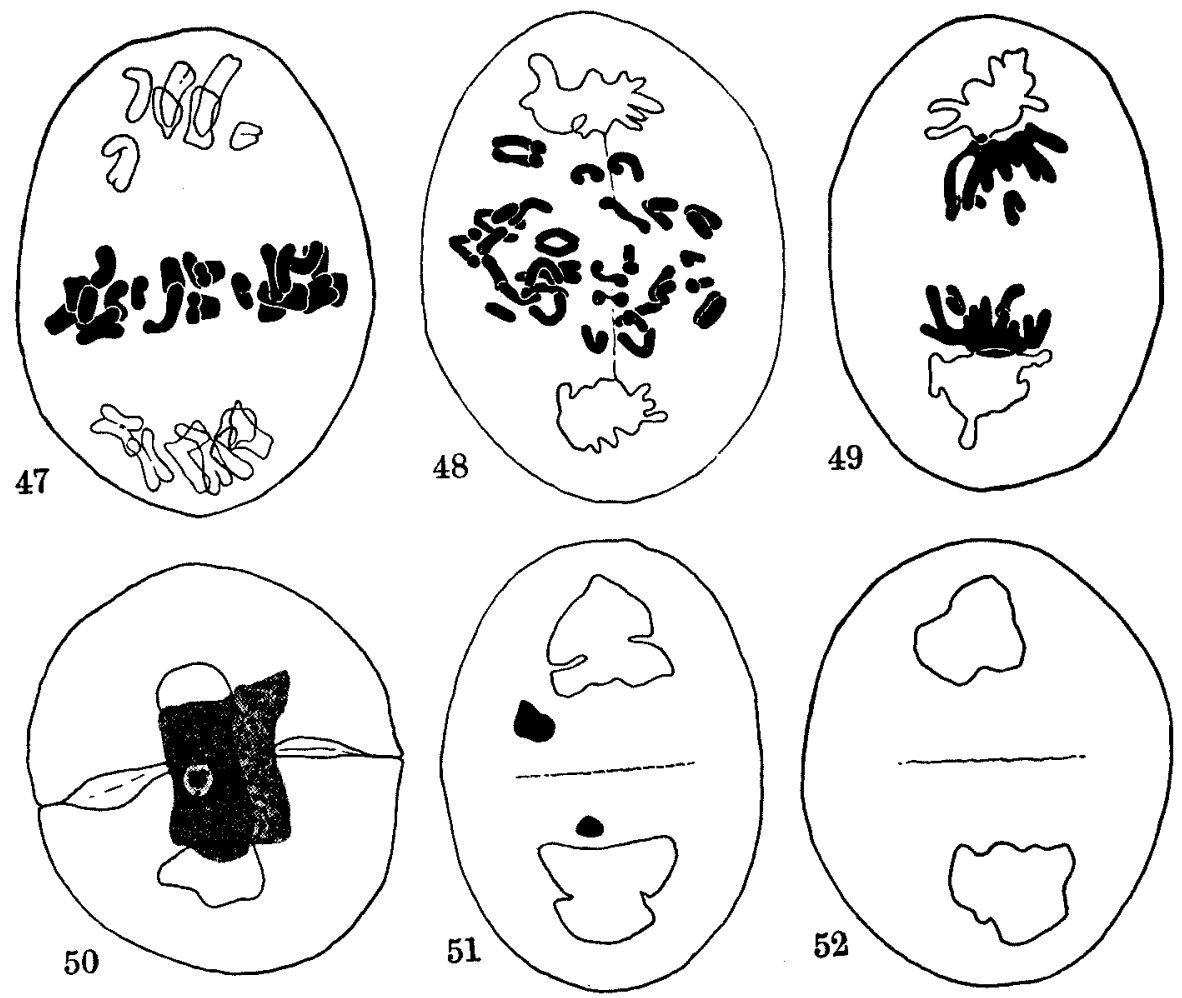

Fig. 43. $1_{\text {III }}+10_{I I}+12_{\text {I }}$.

Fig. 44. Late metilphase. All chromosomes except 1 univalent arrange themselves at the equator. $8 \mathrm{II}+19_{\mathrm{I}}$.

Fig. 45 in and $b$. Polar view of the same stage. $2_{\text {III }}+5$ II $+19_{I}$.

Fig. 46. A tetrepartite chromosome showing the $\mathrm{N}$-configuration.

Fig. 47. Anaphase. All divided halves of 7 bivalents have arrived at each pole and 21 univalents are left at the equatorial plate.

Fig. 48. Telophise. Some lagging univalents are dividing longitudinally and others have been divided.

Fig. 49. 4 chromosome groups are seen.

Fig. 50. Interkinesis. Chromosome clumps are laid between two danghter nuclei.

Fig. 51. Two chromatic bodies are lost in the cytoplism. Daughter nuclei show irregulin shapes.

Fig. 52. A beautiful interkinesis cell.

have also a tendency to be scattered in the cytoplasm at the formation of the equatorial plate of the second division.

Dyads now divide equationally and travel to the poles, while monads do not undergo a further division and remain behind. One of these conditions is given in Fig. 57. It can be seen that some lagging monads 


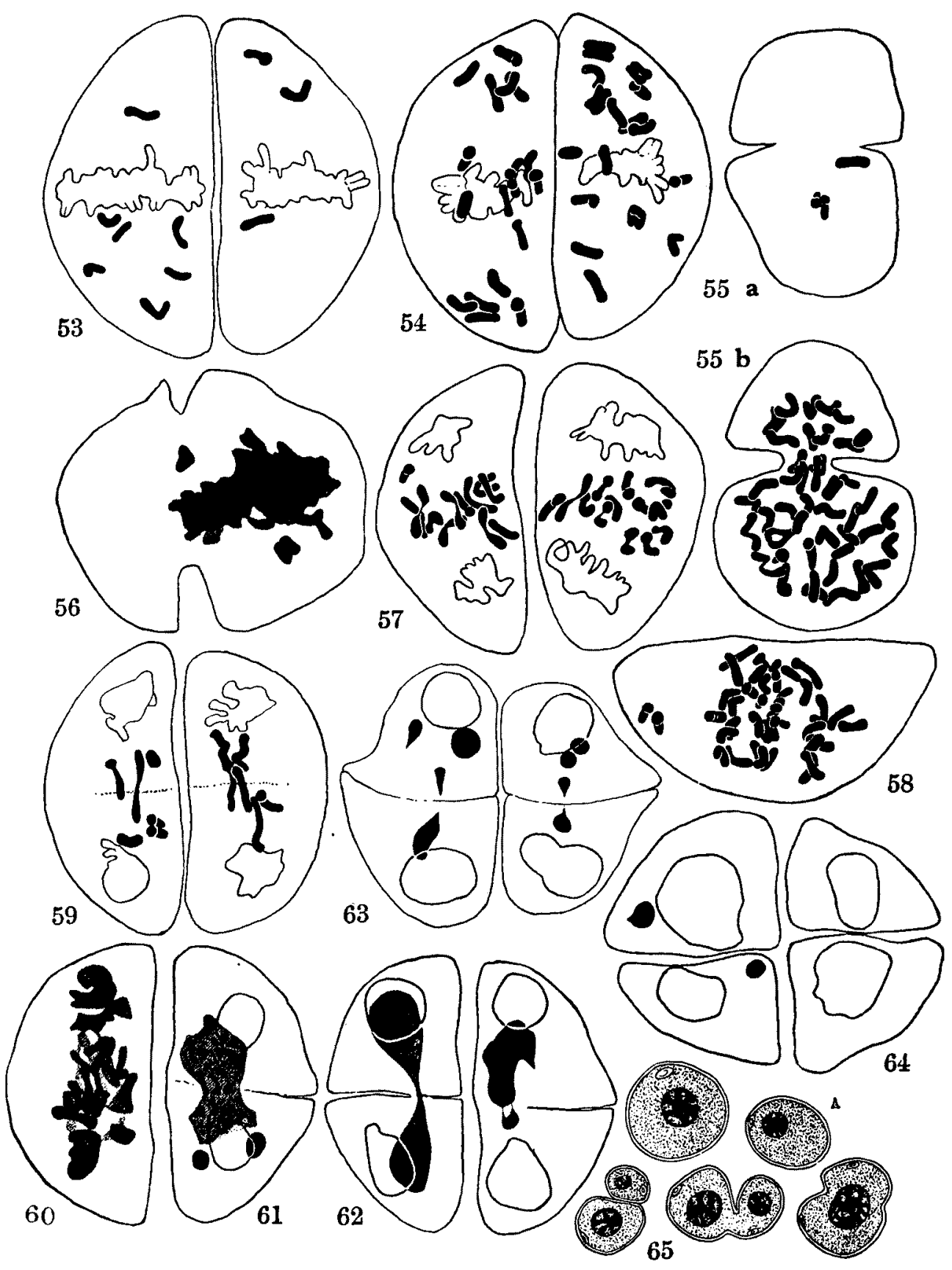


Figs. 53-64. The second maturation division of the $\mathrm{F}_{1}$ from A. barbata $\times$ fatua.

Fig. 53. Side view of metaphase. Some monads are scattered in the cell.

Fig. 54. The same showing very irregular division plates. Aberrant monads and dyads are clearly seen.

Fig. $55 \mathrm{n}$ and b. Polar view of metaphase. 47 chromosomes are exactly counted.

Fig. 56. Side view of the same.

Fig. 57. Anaphase. 13 monads (right) and 12 monads (left) are lagging in the equator. Some monads are markedly constricted.

Fig. 58. Early anaphase. 2 aberrant chromosomes lie near the pole.

Fig. 59. Telophase. Some chromosomes are lost in the cytoplasm.

Fig. 60. Univalents are remaining at the equator and are fusing with each other.

Fig. 61. A large chromosome clump made of monads is passing to the resting stage.

Fig. 62. Chromatic clumps are being cut off by the cell walls into two portions.

Fig. 63. A pollen tetrad with many chromatic bodies besides main nuclei.

Fig. 64. A pollen tetrad sepurated. 4 tetrad nuclei are differing in size.

Fig. 65. Pollen grains representing various shapes and sizas.

are very constricted. Lagging chromosomes increase again in number compared with those at the metaphase but are fewer than the total number of univalents rising at the metaphase of the first division. Shortly after they move at random to join to the reformed nucleus, though some frequently fail to join. In a number of PMC most lagging chromosomes are left at the central region of a cell and associate themselves in a large chromatic clump (Fig. 60). They lose gradually their staining capacity to hämatoxylin and become the resting stage of the nucleus (Fig. 61). Finally by cytokinesis this clump is constricted and separated into two portions or the entire mass is enclosed in one of two daughter cells (Fig. 62). Thus monads show greater irregularities in their behavior at the anaphase and the telophase of the second division than the univalents at the first divisiou.

Many supernumerary nuclei are found in young pollen tetrads as shown in Fig. 63, but generally four pollen grains are formed from one P M C. Sometimes some microspores show abnormal appearances as in the triploid hybrid (Fig. 65).

In Figs. 55 a and $\mathrm{b}$ about 47 chromosomes are counted at the metaphase of the second division. Fig. 56 was also drawn from side views of the same condition of $P$ M C. Such figures may have resulted from an interkinesis cell as shown in Fig. 50 of which cytokinesis incompletely took place for prevention of a chromosome mass lying at 
the central region of the cell. It is, so to speak, a kind of restitution nuclof which were observed in the meiosis of many other hybrids. BRIEGER (1928) discussed and classified modes of increase of chromosome numbers by an abnormal meiotic division. Following his classification this case may be regarded as a modified case of the Type II.

\section{d. A. barbata Ротт $\times$ A. sterilis $\mathrm{L}$.}

The somatic chromosome number of this hybrid was determined to be 35 as was expected (Fig. 66). The cytological behavior during the meiosis of $\mathrm{PMC}$ is quite similar to that in $A$. barbata $\times$ fatua except for the occurrence of a larger number of bivalents. A statistical count on the frequency of the number of bivalents is given in Table 12.

Table 12. Frequency of the number of bivalents and trivalents in A. barbata $\times$ sterilis in 1928 . Count made at the stage shown in Fig. 67.

\begin{tabular}{c|rrrrrrr|r}
\hline \hline III II & 7 & 8 & 9 & 10 & 11 & 12 & 13 & Total \\
\hline 0 & 4 & 5 & 10 & 5 & 3 & 4 & & 31 \\
1 & 3 & 9 & 5 & 10 & 4 & 3 & 1 & 35 \\
2 & & 6 & 11 & 4 & 3 & 3 & & 27 \\
3 & & & 2 & 2 & 1 & & 1 & 6 \\
4 & 1 & & & & & & & 1 \\
\hline Total & 8 & 20 & 28 & 21 & 11 & 10 & 2 & 100
\end{tabular}

The number of bivalents inclusive of trivalents varies from 7 to 13 , the numbers between 8 and 10 being most common. The mean value is $9.45 \pm 0.148$. Trivalents and tetrapartite chromosomes showing the $\mathrm{N}$-shape are also found in about the same frequency as in the above mentioned hybrid, A. barbata $\times$ fatua. $\mathrm{V}$ - and $\mathrm{Y}$-sbape trivalents are counted in observed numbers as 88 and 33 respectively. Fig. 67 shows a metaphase having such a chromosome conjugation as $1_{\mathrm{III}}+12_{\mathrm{II}}+8_{\mathrm{I}}$. It is seen that 11 univalents showing longitudinal splits are lagging in the equatorial region and divided halves of 12 bivalents have arrived at the poles (Fig. 68). A side view of the same stage is given in Fig. 69.

All figures during the meiosis are generally not so irregular as in A. barbata $\times$ fatua, because of the occurrence of the small number of univalents.

The frequencies of pairings of homologous chromosomes counted on two different pentaploid hybrids are also represented graphically (Fig. 


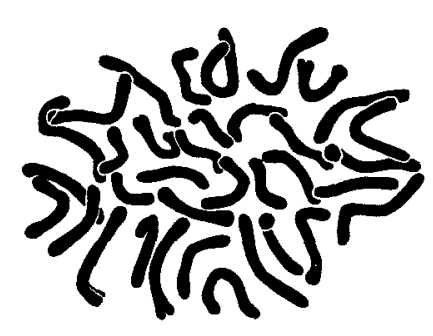

66

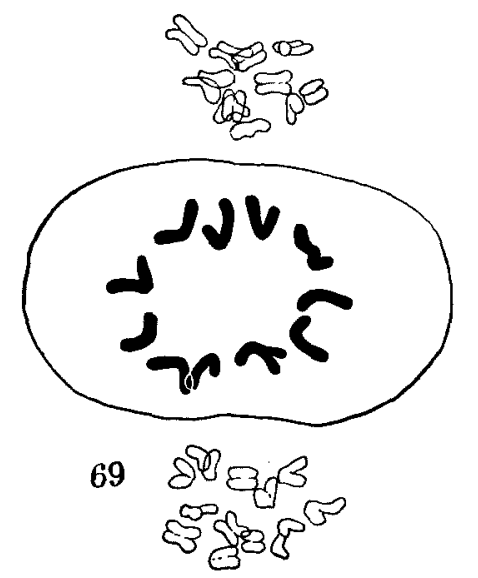

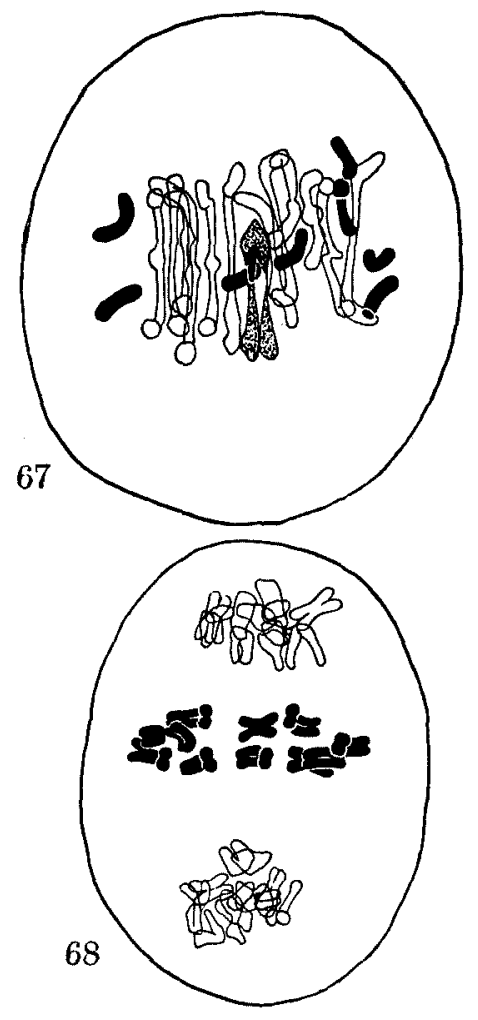

Figs. $66-69$. A. barbata $\times$ sterilis

Fig. 66. Somatic chromosomes, $2 \mathbf{L}=35$.

Fig. 67. Side view of metaphase of the first maturation division of PMC, 1.II $+12_{\text {II }}+8_{\text {I }}$.

Fig. 68. Anaphase. 12 dyads +11 nnivalents +12 dyads.

Fig. 69. Polur view of the same. 12 dyads +11 univalents +12 dyads.

70). The two polygons showing the $A$. barbata $\times A$. fatua data obtained in 1927 and in 1928 deviate little from each other, while there is a significant difference between frequency polygons from $A$. barbata $\times$ fatua and from A. barbata $\times$ sterilis. It is also shown that these polygons coincide closely with the curve of a binominal distribution.

According to DoRsey (1924) the chromo ome behavior during the meiosis of $A$. barbata $\times$ fatua and $A$. barbata $\times$ algeriensis is very different from that in my material. He stated that 14 bivalents and 7 univalents always occurred and all univalents undivided wandered to the poles prior to the division of bivalents. I observed that at the metaphase of the first division most of the univalents had lain near the pole before 


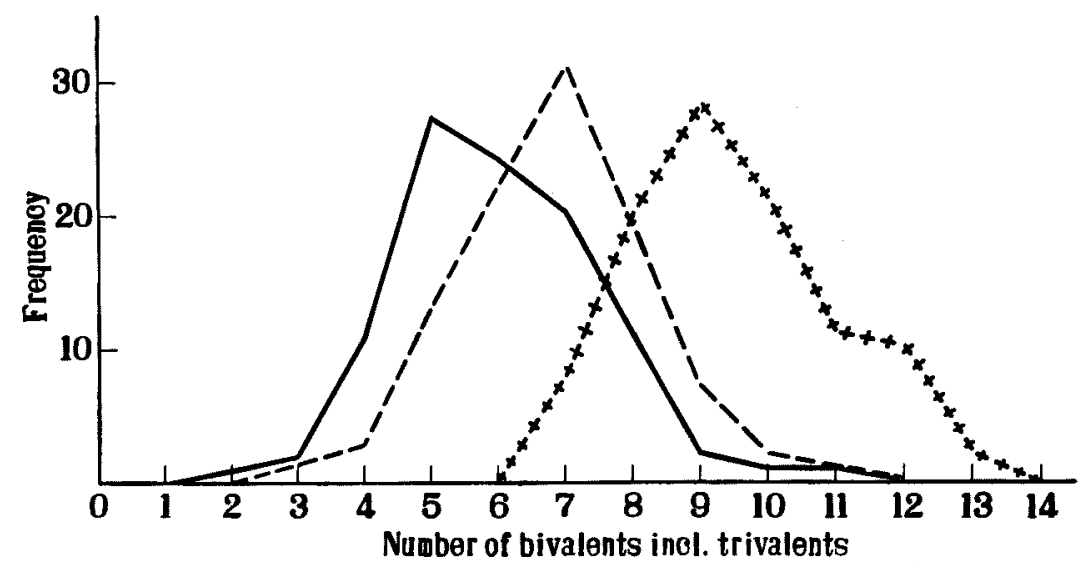

Fig. 70. Frequency polygons of the number of bivalents inclusive of trivalents in pentaploid hybrids.

A. barbata $\times$ fatua in 1927
++ The same in 1928
++++++ A. barbata $\times$ sterilis in 1928

bivalents were divided. Such a meiotic figure is sometimes found in a few preparations but never in others. It seems to be an abnormal figure, probably owing to a division under unfavorable conditions or unsuitable fixing. At any rate it is surprising that Dorser found quite different behavior in the same hybrid.

\section{Cytology of hexaploid hybrids}

The following four hybrids were cytologically studied:
A. fatua L. $\times$ A. sativa L.

$$
" \quad \times A \text {. sterilis L. }
$$
A. sativa L. $\times$ A. byzantina $\mathrm{C}$. KосH.
A. sterilis L. $\times$

All parents have the same chromosome number, 21 in haploid. The somatic chromosome number might be 42 in cach hybrid though this was not examined. At the metaphase of the first division 21 haploid chromosomes are normally found as in the parents (Fig. 71). However a close study of this stage shows that certain irregularities appear with regard to the combination of homologous chromosomes. Each element of 1-2 bivalents occasionally fails to pair and remains as a univalent (Figs. 72-74), while sometimes a univalent mates with a certain bivalent, 
resulting in a trivalent chromosome. Trivalents found here so far represent the V-shape from a side view (Figs. 75 and 77 ).

Frequencies of the occurrence of chromosome irregularities in hexaploid hybrids are givon in Table 13.

Table 13. Frequencies of the occurrence of univalents in hexaploid hybrids. Counts made at the first division metaphase.

\begin{tabular}{|c|c|c|c|c|c|c|}
\hline Nybrids & 0 & 1 & 2 & $\mathbf{3}$ & 4 & $1-4$ \\
\hline A. fatua $\times$ saliva & 95 & & 5 & & & 5 \\
\hline " $\quad \times$ sterilis & 84 & 4 & 12 & & & 16 \\
\hline A. steril is $\times$ byzantina & 71 & 6 & 22 & 1 & & 29 \\
\hline A. satiza $\times \quad$ " & 67 & 5 & 26 & 1 & 1 & 33 \\
\hline
\end{tabular}

When an odd number of univalents was present a trivalent always accompanied them. Trivalents have not yet been observed in the $\mathbf{F}_{1}$ hybrid of A. fatua $\times$ sativa. 'This hybrid has the least frequency of the occurrence of unpaired univalents of the four. In two hybrids, $A$. sterilis $\times$ byzantina and A. sativa $\times$ byzantina, even 4 univalents were rarely observed (Fig. 74). Besides these there was observed a chromosome complex which is evidently distinguished from a normal pair by its stretched, open or twisted ring form (Figs. 76 and 80). Sometimes a ring opens at one side (Figs. 78, 79 and 81). This complex must be composed of 4 elements, therefore, being a tetravalent chromosome, for 19 pairs and a large complex are counted at the metaphase of the first division. This complex is often found in $A$. fatua $\times$ sterilis but rarely in A. sterilis $\times$ byzantina. A univalent and a complex probably consisting of 5 unit chromosomes are shown in Fig. 82. A chromosome chain in Fig. 83 may be formed of 6 components joining end to end.

The behavior of unmated univalents is closely similar to that of a pentaploid hybrid. Fig. 84 shows two split halves of a univalent passing to different poles.

Resemblant phenomena were found in speltoid wheat and other like mutants by Winge (1924) and by Huskins $(1928 \mathrm{a}, \mathrm{b})$ and in fatuoid oats by Huskins (1927, 1928 b). 


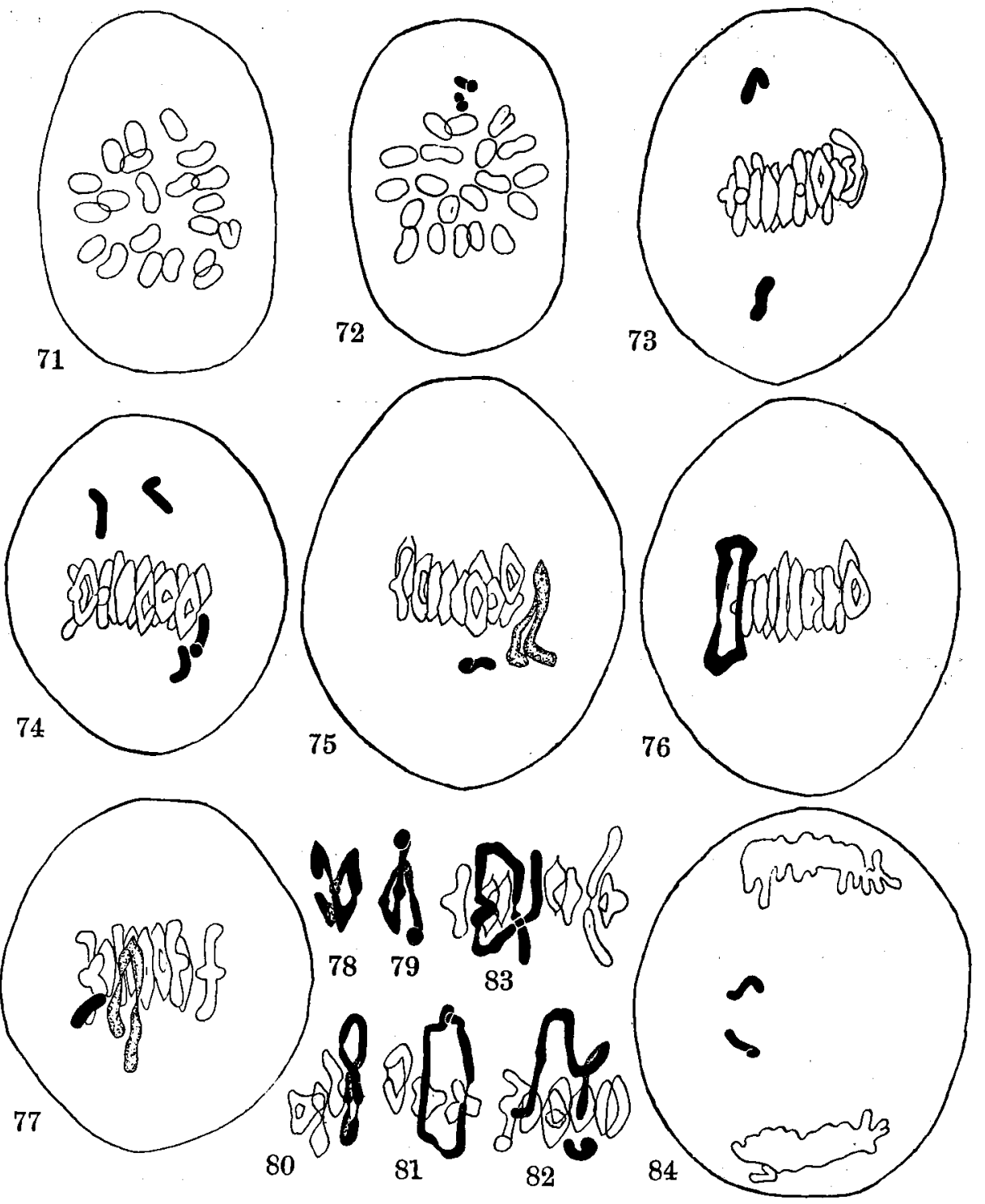

Figs. 71-81. Meiosis of hexaploid hybrias.

Figs. 71-72. A. fatua $\times$ sativa.

Fig. 71. Polar view of metaphase of the first division. 21 II.

Fig. 72. The sume. $20 \mathrm{Ir}+2 \mathrm{~T}$.

Figs. 73-70. A. sterilis $\times$ byzantina.

Fig. 73. Side view of the first division metaphuse with 2 unpaired univalents.

Fig. 74. The same with 4 univalents.

Fig. 75. The same with 1 trivalent and 1 univalent. 
Fig. 76. A liarge chromosome rịng is shown.

Fig. 77. A. sativa $\times$ byzantinx. 1 trivalent and 1 univalent are found, Figs. 78-81. A. fatua $\times$ sterilis.

Fig. 78-79. A tetravalent chromosome. Its 4 elements are arringed in a zigzag but one end is merely opened.

Fig. 80. A tetravalent forming a large ring.

Fig. 81. The sime, of which one end is not closid.

Fig. 82. A univalent and a chromosome complex consisting of 5 components.

Fig. 83. A chromosome chin made of 6 elements mating end to end.

Fig. 81. Telophase of the first division. 2 split halves of a univilent are lagging in the equator.

\section{Chromosome conjugation and nature of polyploidy in Avena.}

As already stated the polyploid series, 7, 14, and 21, exist in the genus Avena, but there is no sufficient evidence to explain how the multiplication of a chromosome number has been carried out. Trabur $(1909-1911)^{1)}$ and VAvilov (1914) suggested that cultivated oats have a polyphyletic origin. Huskins (1927) also has the opinion that hexaploid oats may have been synthetized from two or three primitive diploid species through hybridisations.

Based upon the cytological results of my oat hybrids I shall below discuss the nature of polyploidy in Avena.

Triploid hybrids: In spite of expecting $0-7$ bivalents as in an ordinally triploid hybrid the $\mathrm{F}_{\mathrm{l}}$ of $A$. barbata $\times$ strigosa has $7-9$ bivalents and frequently among them $1-3$ trivalents are met.

At the meiosis of Tradescantia (SANDS 1925) and triploid tomatoes (LesLey, M.M. 1926) a now fact was discovered that a continious spireme was formed by all the chromosome olements until the diakinesis or the metaphase, and later usually broken to a normal number of chromosomes. STow (1927) observed multipartite chromosomes and normal bivalents mixed together at the sporogenesis of Solanum plants kept in a certain condition. Belling (1927) also reported such a chromosome feature in the same plant. Judging from the facts these chromosome complexes would occur owing to the incomplete abstriction of a chain composed of non-homologous chromatic threads.

In the triploid hybrid, at first glance, an excessive number of bivalents and chromosome complexes may appear to be formed of the union of mere univalents in the same manner as in the above cases. But this is probably not true because components forming these com-

1) After 'Thellong (1928). 
plexes are always found in a definite number.

We may analyse to a certain extent the nature of different chromosome sets if we consider the mode of the formation of 9 bivalents in the triploid hybrid. There are three possibilities with respect to the mode of the chromosome conjugation as shown in the following diagrams. Solid lines show bivalent formation and broken lines trivalent formation.

Diagram I: 7 bivalents out of 9 are formed by pairing between 7 strigosa $\left(a_{1}-a_{7}\right)$ and 7 barbata chromosomes $\left(a_{1}-a_{7}\right)$. The other 2 bivalents are made of 4 chromosomes $\left(2 \mathrm{~b}_{1}\right.$ and $\left.2 \mathrm{~b}_{2}\right)$ in the second set of $A$. barbata. The remaining 3 chromosomes $\left(a_{1}-a_{3}\right)$ in the same set may conjugate with 3 bivalents, forming 3 trivalents.

Diagran II : All 14 barbata chromosomes $\left(a_{1}-a_{7}\right.$ and $\left.a_{1}-a_{7}\right)$ pair with one another and the other 2 bivalents are also formed by autosyn-

\section{Diagram I}

\section{A. barbata}

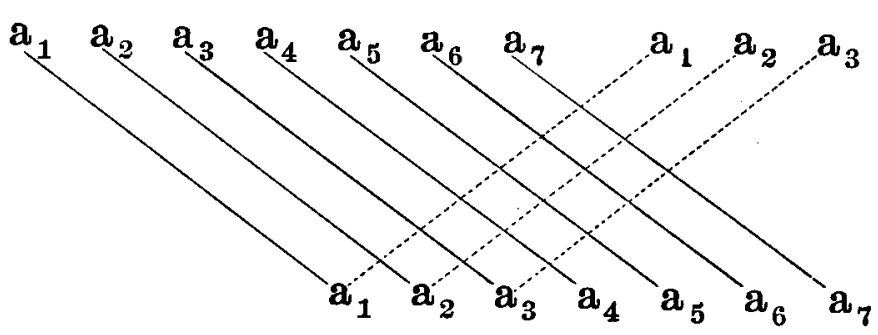

$\begin{array}{llll}b_{1} & b_{1} & b_{2} & b_{2}\end{array}$

A. strigosa

Diagram II

A. barbata

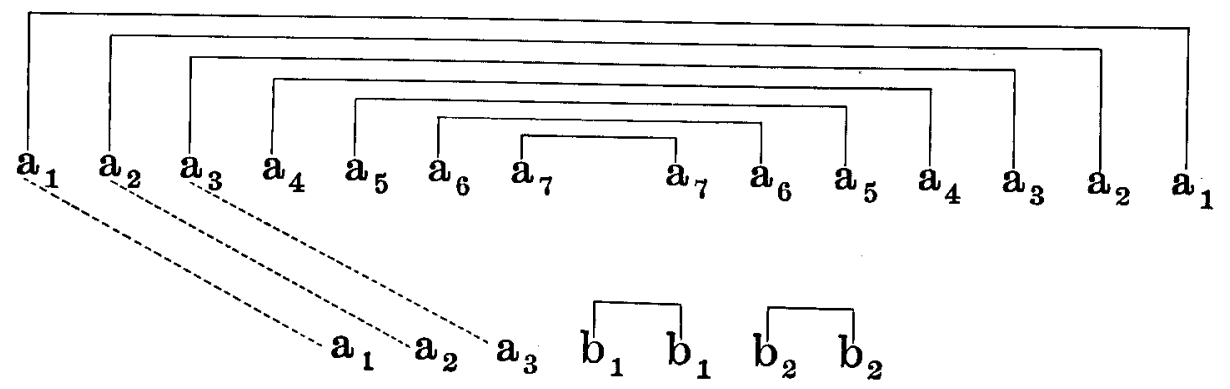

A. strigosa 
Diagram III

A. barbata

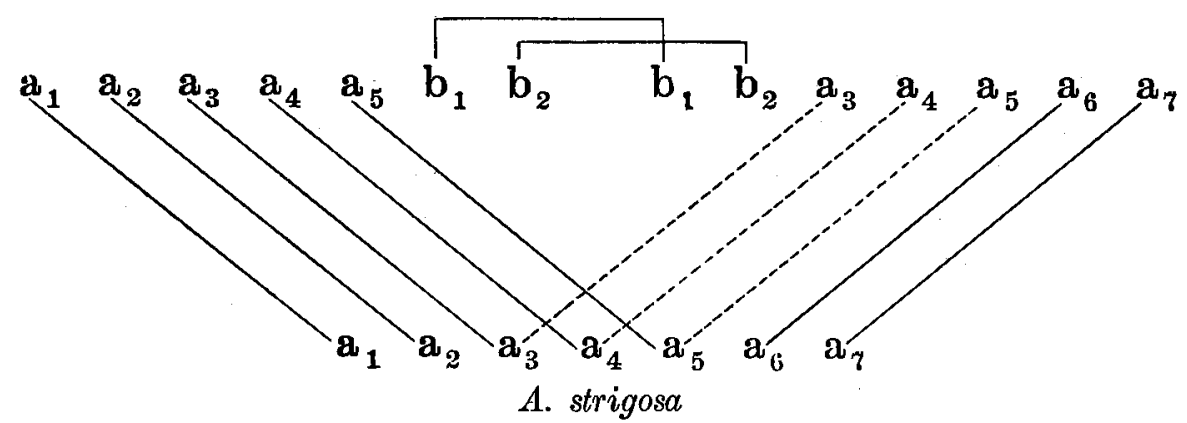

desis of 4 strigosa chromosomes $\left(2 b_{1}\right.$ and $\left.2 b_{2}\right)$. The remaining 3 chromosomes of $A$. strigosa $\left(a_{1}-a_{3}\right)$ mate secondarily with 3 bivalents made of barbata chromosomes.

Diagram III : 7 strigosa chromosomes $\left(a_{1}-a_{7}\right)$ pair partially with certain chromosomes of the first and second sets of $A$. barbata $\left(a_{1}-a_{5}\right.$ and $\left.a_{6}-a_{7}\right)$. The 2 surplus bivalents are formed by autosyndesis among barbata chromosomes belonging to different sets $\left(2 b_{1}\right.$ and $\left.2 b_{2}\right)$.

Before discussing these types of chromosome mating, I shall review some cases in which autosyndesis may have been occured. HaAseBesser, G. (1921) observed 36 pairs at the diakinesis in the meiosis of the $\mathrm{F}_{1}$ hybrid between Digitalis lutea with 48 haploid chromosomes and D. micrantha with 24 . She assumed that 24 lutea chromosomes out of 48 werc forced to mate with one another and these formed 12 pairs. She further stated that the basic chromosome number of Digitalis may be 12, not 24. Recently Buxton and Newton (1928) has stated that the haploid chromosome number of $D$. micrantha used by HAAsE-BEsseL seems more probably to be 28 as in other Digitalis species studied by them. Analogous chromosome mating was reported by CoLLINs and MaNN (1923) and BABCocr (1924) in the Crepis hybrid. The hybrid had 24 somatic chromosomes, being contributed from $C$. setosa. HALL. by 4 and $C$. biennis L. by 20. At the diakinesis 10 bivalents and 4 univalents were counted. It is evident that 20 chromosomes from $C$. biennis had paired with each other. LJUNGDAFI (1924) reported that 21 bivalents were observed in the meiosis of Papaver hybrids, $P$. striatocarpum $(\mathbf{n}=35) \times P$. nudicaule $(\mathrm{n}=7)$ and $P$. nudicaule $(\mathrm{n}=7) \times P$. radiatum $(\mathbf{n}=\mathbf{3 5})$. It seems to be the most reasonable hypothesis that 7 bivalents are formed by allosyndesis and the other 14 bivalents must 
be made by autosyndesis among 28 chromosomes of decaploid parents. The same feature of the chromosome behavior in certain Solanum plants is found by Jorghensen (1928) and in the $\mathrm{F}_{1}$ from Betula pubescens $\times$ verrucosa by JERGENSEN and Herms (1925)"

All these authors assumed that autosyndesis must have taken place between homologous clromosomes derived from different sets of chromosomes of the higher polyploid parent and never from the same set. Their hypothesis was fully confirmed as correct by the cytology of haploid mutants.

Recently the occurrence of haploid plants has often been reported, for example ;

Datura stramonium (Blakeslee, Belling, Farnham and Bergner 1922, Belisng 1927), Nicotiana tabacum (Clausen and MaNn 1924, ChIPManN and Goodspeed 1927), Triticum compactum (Gaines and AAse 1926), Crepis capillaris (Holdingshead 1928), Solanum Lycopersicum (LINDSTROM 1929).

Lessey, M. M. and Forst (1928) found a "disomic haploid" in $\mathrm{F}_{2}$ progenies of a varietal cross of Matthiola incana. All these haploid except one in Crepis, of which meiosis has not yet been studied, carried out a sort of reduction division at spore formation. This division is, however, entirely different from that of a diploid plant in point of no conjugation of chromosomes. However it was reported that occasionally one loose pair of chromosomes and rarely more were observed in the haploid wheat. Their occurrence would be naturally expected from KIHARA and Nishiyama's investigations (1928) on various wheat hybrids where among chromosomes from three different sets (A, B and D) $0-6$ pairings could be formed. Jargensen (1928) mentioned an interesting chromosome behavior of a haploid Solanum nigrum. At the first maturation division of this mutant chromosome pairing approaches the scheme $12_{\mathrm{II}}+12_{\mathrm{I}}$ as in a triploid hybrid. This surprising phenomenon is clearly understood from the fact that diploid Solanum nigrum may bo phylogenetic hexaploid. In his studies of Ribes Gordonianum Tisculen (1928) reported one exceptional case in which pairings occurred between chromosomes belonging to one and the same genom, but a little later MevRMan (1928) who studied the same and other Ribes hybrids in detail denied wholly Trschler's assumptions. Thus apparently none of chromosomes from one set or among chromosomes belonging to the same genom mate with one another

1) After Gangengen (1928). 
Returning now to the mode of chromosome mating in the triploid oat hybrid, Diagram I and II have 2 autosyndetical bivalents derived from one chromosome set of $A$. strigosa or $A$. barbata. As above fully discussed the modes of chromosome binding are not probable. In Diagram II also 7 bivalents are taken to represent pairings between two sets of 7 barbata chromosomes. If this be true, in the $\mathrm{F}_{1}$ from $A$. barbata $\times$ fatua, always at least 7 bivalents ought to have been found. But this is not the case. Diagram III seems to be most adequate because the mode shown is not contrary to all these points.

If we should find 10 bivalents in this hybrid a modified conjugation of Diagram III might be taken as follows:

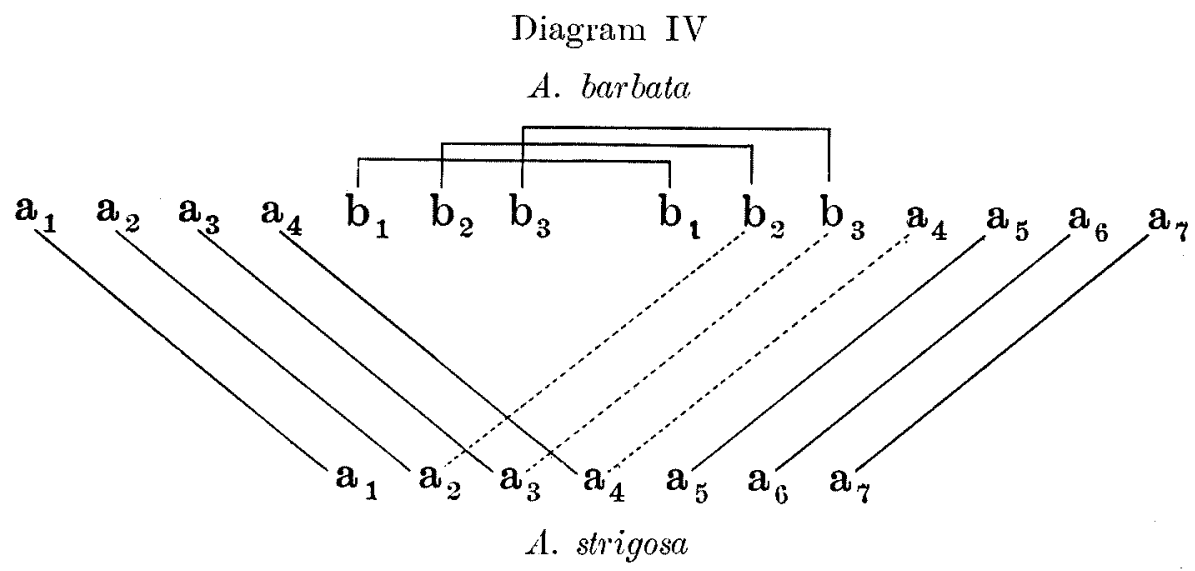

In this case two tetrapartite chromosomes which will be discussed bclow are able to occur but commonly these complexes may be separated into 2 bivalents or 1 trivalent and 1 univalent.

Representing two genoms of $A$. barbata as A and B, 14 barbata chromosomes are again shown as follows:

$$
A a_{1}+a_{2}+a_{3}+a_{4}+a_{5}+b_{1}+b_{2}+B a_{3}+a_{4}+a_{5}+a_{6}+a_{7}+b_{1}+b_{2}
$$

If in Diagram III $\mathrm{B}_{2}$ is slightly capable of pairing with $\mathrm{a}_{2}$ of $A$. strigosa though $A_{i_{2}}$ is not homologous with $A_{b_{2}}$ the sccondary mating between 2 bivalents, $A_{i_{2}}-a_{2}$ and $B_{b_{2}}-A_{b_{2}}$, may rarely occur and such a chromosome complex as $\left.\right|_{\mathbf{b}_{2}-A_{b_{2}}} ^{A_{u_{2}}-a_{2}}$ may result. In this case a closed ring is not formed, for $A_{a_{2}}$ and $A_{b_{2}}$ are not homologous with each other, being unable to mate. A chromosome complex showing the $\mathrm{N}$-configuration seems to suggest a possibility of such a chromosome conjugation. 
Hence it may not be a tetravalent but a tetrapartite chromosome. We can not find also theoritically 4 homologous chromosomes in a triploid hybrid. $\mathrm{N}$-shape chromosome complexes found in interspecific wheat hybrids by Kinara and Nishiyama(1928) and in Humulus Lupulus by Shinotô(1929) are probably analogous to this case. According to BeLLing (1927) a tetravalent chromosome showing the $\mathrm{N}$-shape has not yet been found in tetraploid Daturas having all possible configurations of tetravalents. In the light of this evidence it may also be suggested that the present tetrapartite chromosome may be a peculiar complex derived from the union of 2 bivalents. HAKansson (1929) observed that in the hybrid between certain lines of Pisum 2 definite bivalents paired with one another.

Recent cytological works show that in many triploid plants and progenies from certain polyploid hybrids some trivalent chromosomes are often formed together with normal bivalents. KinARA and Nishiyama (1928) reported in their recent paper on Triticum hybrids that trivalent chromosomes are sometimes found in varying number besides normal bivalents and univalents, representing a remarkable similarity to those of Avena hybrids.

Pentaploid hybrids: Two pentaploid hybrids, A. barbata $\times$ fatua and A. barbata $\times$ sterilis, show that a varying number of bivalents and trivalents are found at the maturation division, the highest numbers so far found being 11 in the former and 13 in the latter.

The chromosome behavior follows nearly the Drosera scheme $14_{\mathrm{II}}+$ $\tau_{1}$, but there is no sufficient evidence for such a chromosome conjugation as that in which 14 barbata chromosomes pair with 14 from $A$. fatua or $A$. sterilis and the remaining 7 chromosomes of the latters remain unpaired. Although none of 14 barbata chromosomes is homologous with any one of $A$. fatua, we may expect 5 pairs produced by autosyndesis of 10 barbata chromosomes. If the cytological behavior of a tetraploid hybrid viz. A. strigosa $\times$ fatua be cleared up we can know the constitution of 21 haploid chromosomes of the latter species. We have, however, at present no knowledge of their nature. Therefore, the mode of chromosome pairing in pentaploid hybrids remains a problem for the future.

Hexaploid hybrids: In the majority of cells a full pairing $\left(21_{\mathrm{II}}\right)$ is found though sometimes 1-4 univalents, rarely a trivalent and a tetravalent chromosome are observed. From these cytological results, and from genetic facts reported by earlier investigators it may be concluded that each of 21 chromosomes from one parent usually mates with a definite one from the other parent.

With regard to the occurrence of univalents there are two possi- 
bilities. One is the failure of mating between 2 homologous chromosomes and the other is faulty mating between 2 chromosomes from 2 semihomologous bivalents. In the former case 2 or 4 univalents are homologous with two another, while in the latter case they are not normal partners of bivalents. Considering the formation of trivalents and tetravalents the latter case seems to be more probable. For example, if the pairs are $\underset{a^{\prime}}{a}$ and $b_{b^{\prime}}^{b}$ and they are semi-homologous with each other it is conceivable that a may sometimes mate with $b^{\prime}$ leaving $a^{\prime}$ and $b$ as univalents. When $b^{\prime}$ conjugates $\underset{a^{\prime}}{a}$ a trivalent, $\underset{a^{\prime}}{a} b^{\prime}$, and a univalent, $b$, arise. Tetravalent chromosomes are made by conjugation of 2 semi-homologous bivalents,

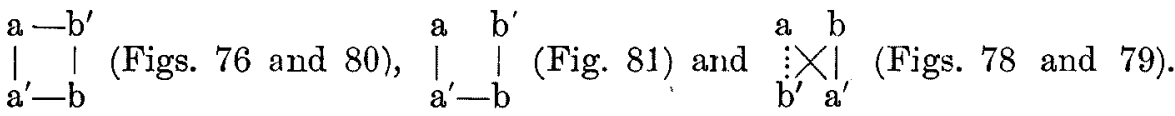
Figs. 82 and 83 show such chromosome complexes as $\frac{b^{\prime}-c}{b-a^{\prime}-a}+c^{\prime}$ and $b-a^{\prime}-a$ $b^{\prime}-c-c^{\prime}$ respectively. It is difficult to distinguish $a, b$ and $c$ without careful observations because they are not distinctly different in shape and size. Therefore, the arrangement of elements of these chromosome complexes is merely an example. In his studies on Rumex and Oenothera KiHARA $(1925,1927)$ discussed in great detail the formation of chromosome complexes.

From the occurrence of certain irregularities, at any rate, it is evident that there is more or less affinity to mate among unusual partners of bivalents. The formation of chromosome complexes give also evidence that 42 -chromosome oats are hexaploid. My cytological results do not give a sufficient proof that these oats are autohexaploid but rather tend to allohexaploid as stated by Huskins (1927, 1928).

WrNge (1924) and Huskins (1927) accounted for speltoid and fatuoid mutations respectively on the same principle. In the same way Goulden (1925) and Trompson (1928) also explained dwarfing in wheat of which the inheritance is very complex. Studying further on speltoid wheats and fatuoid oats Huskivs (1928 a, b) emphasized his chromosome aberration hypothesis regarding origins of these mutants. Based on the cytological results in various of my oat hybrids the chromosome aberration 
seems to be caused through a crossing between oat species or varieties. Investigations on this problem are now in progress, of which a detailed report will be published in the near future.

\section{Chromosome affinity among Avena species}

It is generally accepted that the closer two species are related the stronger the chromosome mating which is formed at the meiosis of the hybrid between them. The writer attempts to represent the intensity of the chromosome affinity between two species by the proportion of the number of bivalents inclusive of trivalents found in the hybrid to that expected. If two parents differ in chromosome numbers, as many bivalents as the lower chromosome numbers of one parent may be expected. A full affinity between two species is, therefore, represented as 1.000 and non-affinity is shown as 0.000. Chromosome affinities among Avena species counted by this method are given in Table 14. In these counts the results in Table 4, 11 and 13 are used as the observed number of bivalents.

Table 14. Chromosome affinities among Aveva species

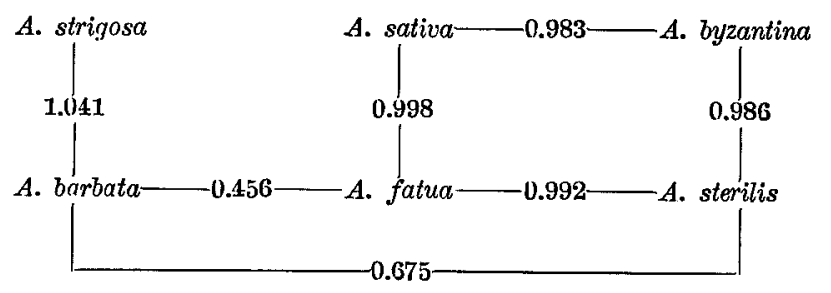

The chromosome affinity between $A$. strigosa and $A$. barbata exceeds the full affinity by 0.041 . This is entirely due to autosyndesis of barbata chromosomes. A. barbata is not closely related with $A$. fatua and $A$. sterilis especially with the former, while the affinities among hexaploid species are generally great, approximately a full affinity. In general, the chromosome affinity between diploid and tetraploid species is high, but low between tetraploid and hexaploid species. The reverse is true in the genus Triticum. Thus chromosome relationships are in good agreement with Thellung's phylogenetic tree in Avena. 


\section{Summary}

1. One triploid hybrid, Avena barbata $\times$ strigosa, two pentaploid hybrids, $A$. barbata $\times$ fatua and $A$. barbata $\times$ sterilis, four hexaploid hybrids, A. fatua $\times$ sxtiva, A. fatua $\times$ sterilis, A. sativa $\times$ byzantina and $A$. sterilis $\times$ byzantina, and their parents were studied morphologically and cytologically.

2. Triploid, pentaploid and hexaploid hybrids were obtained by artificial pollinations with no difficulty, but I failed to get tetraploid hybrid plants in the crosses, $A$. strigosa $\times A$. fatua and $A$. sterilis, and in the reciprocal crosses.

3. Triploid and pentaploid hybrids in question are highly sterile, but the fertility varies to some extent. All hexaploid hybrids are as completely fertile as their parents.

4. With regard to the following characters $F_{1}$ hybrids are generally intermediate; the wide spreading character of culms in early growing stages, color of nodes, wax on sheaths, type of ears, number of spikelets per ear, pubescence on lemmas and lateral sides of bases of the first florets, lenghts of empty glumes, lemmas and awns. Lengths of culms of triploid and pentaploid hybrids are longer than those of either parent but the remaining hybrids have intermediate lengths.

5. The following characters are considered to be dominant; solid bases, awnlessness and smoothness of the second floret, no pubescence on the dorsal side of the base of the first floret, brown to dark brown color of lemmas.

6. In the triploid hybrid, the dominancy of smoothness of bases, pedicels and lemmas as well as non-disarticulation of all florets are converted to recessiveness.

7. The following chromosome numbers have been counted in P M C ; 7 for A. strigosa, 14 A. barbata, 21 A. fatua, A. sativa, A. sterilis and $A$. byzantina. In all these species the sporogenesis is quite normal and no significant irregularities appear.

8. At the first division metaphase of $\mathrm{PMC}$ of the $\mathrm{F}_{1}, A$. barbata $\times$ strigosa, 7 bivalents inclusive of trivalents are found in common, but sometimes $8-9$ bivalents are clearly counted. The number of trivalents is $0-3$ and their configuration is $\mathrm{V}$ or sometimes $\mathrm{Y}$. Besides these there is rarely a tetrapartite chromosome showing the $\mathrm{N}$-shape. Two components of each bivalent conjugate closely as in their parents.

9. The modes of chromosome pairing in this hybrid are discussed at length (See Diagram I-IV). 
10. In the early metaphase of the first division bivalents and trivalents form a normal equatorial plate but univalents are irregularly scattered in the cell. In the following stage all univalents are generally arranged at the equator arround the bivalents.

11. Univalents are left behind bivalents when the latter pass to the spindle poles, but immediately afterward univalents divide equationally and the two halves go to different poles. They are frequently not separated and both lying side by side travel to one pole.

12. At the telophase splitting halves of univalents, and entire univalents are often lost in the cytoplasm.

13. The metaphase of the second division is beautiful but some monad and dyad chromosomes are occasionally located outside the equator.

14. Dyad chromosomes are longitudinally divided and their halves go to opposite poles. While monad chromosomes without further division are distributed at random to the poles but some are absent from reformed nuclei.

15. Frequencies of the number of lagging chromosomes at several stages during the meiosis are statistically examined. The number of lagging dyads decreases less and less throughout the maturation divisions, while frequencies of loss of monads undergo fluctuation at different stages. The mode of frequency distribution of lagging monads becomes less and less as the process of the maturation divisions progresses. It is, however, again extraordinarily increased at the anaphase of the second division. The phenomenon may have arisen from the different behavior of monads in comparison with dyads.

16. Most pollen tetrads are composed of four cells. Although appearances of most of the young pollens are normal many of them become almost empty or have a scanty content at the time of ripening.

17. In the pentaploid hybrids the meiosis of $\mathrm{PMC}$ proceeds in the same way with that of the triploid hybrid except in the following two paragraphs.

18. Chromosome conjugations are generally loose. Two components of a bivalent mate usually only at one end. 2-11 bivalents and frequently among them 1-4 trivalent; are found in the hybrid of $A$ barbata $\times$ fatua, and $7-13$ bivalents inclusive of $0-4$ trivalents in the $\mathrm{F}_{1}$ between $A$. barbata and $A$. sterilis.

19. At the anaphase of the first division most of the lagging univalents are divided and the halves are included in daughter nuclei. But a few monad chromosomes are sometimes lost in the cytoplasm 
of the interkinesis cell. The second division is very irregular because of the occurrence of many lagging monads.

20. All hexaploid hybrids have normal 21 bivalents in the majority of $\mathrm{PMC}$ at the metaphase of the first division. Sometimes 1-4 univalents and certain chromosome complexes are found together with normal bivalents. These irregularities are probably caused by mating between semi-homologous chromosomes, not being normal partners.

21. Cytological relationships among Avena species agree fairly with the genealogical tree proposed by Thellung $(1911,1928)$.

In conclusion, the writer wishes to express his heartiest thanks to Prof. H. Kinara under whose direction this investigation has been carried out.

\section{Literature}

BABcock, E. B. (1924). Species hybrids in Crepis and their bearing on evolution. Amer. Nat. 58.

BeLIING, J. (1927), The attachments of chromosomes at the reduction division in flowering plants. Journ. Gen. 18.

Blakeglee, A. F., Belting, J., Farnha M, M. L. and Bergner, A. D. (1922). A hiploid mutint in the Jimson weed, "Datura stramonium". Science 55.

BLEIRR, H. (1928). Zytologische Untersuchungen an seltenen Getreide- und Rübenbastarden. Zeitschr. f. ind. Abst. u. Vererb. Supp. Bd. 1.

Brieger F. (1928). Ǘber die Vermehrung der Chromosomenzlhl bei dem Bastard Nicotiana tabıcum L. $\times N$. Rusbyi Britt. Zeitschr. f. ind. Abst. u. Vererb. 17.

Buxton, B. H. and Newron, W. C. F. (1928). Hybrids of Digitalis ambigua and Digitalis purpurea, their fertility and cytology. Journ. Gen. 19.

Chrpyan, R. H. and Goodspeed, T.H. (1927). Inheritince in Nicotiana tabacum. VIII. Cytological features of purpurea haploid. Univ. Culif. Publ. Bot. 11.

Cuausen, R. E. and Mann, M. C. (1924). Inheritince in Nicotiana tabacum. V. The occurrence of haploid plants in interspecific progenies. Proc. Nit. Acid. Sci. 10.

Cleland. R. E. (1923). Chromosome arringements during meiosis in certain Oenotheras. Amer. Nat. 57.

(1924). Meiosis in pollen mother cells of Oenothera franciscana sulfurea. Bot. Mig. 77.

- (1926). Meiosis in the pollen mother cells of Oenothora biennis and Oenothera biennis sulfurea. Genetics 11.

Collins, J. L. and MaNN, M. C. (1923). Interspecific hybrids in Crepis. II. A preliminary report on the results of hybridizing Crepis setosa Hall. with C. capillaris (L.) Wallr. and with C. biennis L. Genetics 8.

Darrnogton, C. D. (1928). Studies in Prunus. I and II. Jonrn. Gen. 19.

Donsey, E. (1924). Cytological studies of the maturation divisions in cereul hylurids. An abstract of a Cornell University thesis. 
Etheridge, W. C. (1916). A classification of the varieties of cultivated onts. Corn. Univ. Agr. Exp. St. Mem. 10.

Games, E. F. and AsSe, H. C. (1925). A haploid wheat plant. Amer. Journ. Bot. 13.

GodLden, C. H. (1925). A genetic and cytological study of dwarfing in wheat and oats. Univ. of Minnesota, Agr. Exp. St. Tech. Bull. 33.

HaASe-Bessell, G. (1921). Digitalisstudien II. Zeitschr. f. ind. Abst. u. Vererb. 27.

Heпrons, O. (1924). Chromosome numbers and dimensions, speciesformation and phylogeny in the genus Carex. Hereditas 5.

(1928). Chromosome studies in Cypernceae. Hereditas 11.

Hravacer, J. (1928). Die Bustardierungstechnik beim Hafer. Českoslov, Zěmed. 10. Abstract. Fortschritte Landwirtschaft 4. (1929).

Holdingshead, L. (1928). A preliminary note on the occurrence of haploids in Crepis. Amer. Nat. 62.

Huskins, C. L. (1927). On the genetics and cytology of fatuoid or false wild oats. Journ. Gen. 18.

(1928 a). On the cytology of speltoid wheats in relation to their origin and genetic behaviour. Journ. Gen. 20.

(1928 b). Genetical and cytologicnl studies of fatuoid oats and speltoid wheats. Zeitschr. f. ind. Abst. u. Vererb. Supp. Bd. 2.

Hâkansson, A. (1926). Über das Verhalten der Chromosomen bei der heterotypischen Teilung schwedischer Oenothera Lamarckiana und einiger ihrer Mutanten und Bastarde. Hereditas 8.

(1928). Die Reduktionsteilung in den Sumenanlagen einiger Oenotheren. Hereditas 11.

(1929). Chromosomenringe in Pisum und ihre Mutmassliche genetische Bedeutung. Hereditas 12.

Jargensen, C. A. (1928). The experimental formation of heteroploid plants in the genus Solanum. Journ. Gen. 19.

KaGAWA, F. (1928). Cytological studies on Triticum and Aegilops. II. On the genus crosses between Triticum and Aegilops. Japan. Journ. Bot. 4.

KinaRa, H. (1919). Über cytologische Studien bei einigen Getreidearten. Mittejlung $\Pi$. Chromosomenzahlen und Verwantschaftsverhaltnisse unter Avena-Arten. Bot. Mag. Tokyo 33.

(1924). Cytologische und genetische Studien bei wichtigen Getreidearten mit besonderer Rücksicht auf das Verhalten der Chromosomen und die Sterilität in den Bastarden. Mem. Coll. of Soi. Kyoto Imp. Univ. B. 1.

(1925). Chromosomes of Rumex acetosella L. Bot. Mag. Tokyo 39.

(1927). Über das Verhalten der "end to end" gebundenen Chromosomen von Rumex acetosella and Oenothera biennis während der heterotypischen Kernteilung. Jahrb. wiss. Bot. 66.

KrHaRA, H. and ONo, T. (1926). Chromosomenzahlen und systematische Gruppierung der Rumex-Arten. Zeitschr. f. Zell, u. mikr. Anat. 4.

Krgara, H. and Nishryama. I. (1928). New aspects of chromosome behavior in pollen mother-cells of tri-, tetri-and pentaploid wheat hybrids. Bot. Mag. Tolkyo
42.

Leslex, M. M. (1926). Maturation in diploid and triploid tomatoes. Genetics 11.

Lescey. M. M. and Frost, В. B. (1928). Two extreme "small" Matthiola plants : A haploid with one and a diploid with two additional chromosome fragments. Amer. Nat. 62.

Lindstrom, E. W. (1929). A haploid mutant in the tomato. Journ. Hered. 20. 
IJUNGDAHL, H. (1924). Über die Herkunft der in der Meiosis konjugierenden Chromosomen bei Papaver-Hybriden. Svensk Bot. Tidskr. 18.

Metibura, M. C. and Thompson, W. P. (1927). The cytology of a tetraploid wheat hybrid (Triticum spelta $\times$ T. monococcum). Amer. Journ. Bot. 14.

Mgunman, O. (1926). IBeiträge zur Falktorenanalyse des Hafers. I. Zeitsohr. f. Pflanzenz. 12.

(1928). Cytologieal studies in the genus Ribes L. Hereditas 11.

N ${ }_{\triangle G A O}$, S. (1929). Karyological studies of the Narcissus plant. I. Somatic chromosome numbers of some garden varieties and some meiotic phases of a triploid variety. Mem. Coll. of Sei. Kyoto. Imp. Univ. B. 4.

NILsson-EHr, H, H. (1911). Über Falle spontanen Wegfallens eines Hemmungsfaktors beim Hafer. Zeitschr. f. ind Abst. u. Vererb. 5.

NishiraMa, I. (1928). Reduction division in Lycoris. Bot. Mag. Tokyo. 42.

Percrad, J. (1926). The morphology and cytology of some hybrids of Aegilops ovata L. 우 $\times$ wheats ㅇ․ Journ. Gen. 17.

RosenBmRG, O. (1917). Die Redultionsteilung und ihre Degeneration in Hieracium. Svensk Bot. Tidskx. 11.

(1927). Die semiheterotypische Teilung und ihre Bedeutung für die Entstehung verdoppelter chromosomenznhlen. Hereditas 8 .

SANDS, H. C. (1925). A microdissection of the pachytene threads of Tradescantia virginica L. Journ. Gen. Phys. 9.

Sirorô, Y. (1927). Microsporogenesis in Oenothera sinuata L. Bot. Mag. Tokyo, 41.

(1929). On the tetrapartite chromosome in Humulus Lupulus. Proc. Imp. Acad. 5. Japan.

Stanton, T. R. and Dorsey, E. (1927). Morphological and cytologicul studies of an oat from Ethiopia. Journ. Amer. Soc. Agron. 19.

StouzE, K. V. (1925). Die Chromosomenzahlen der hauptsischlichsten Getreidearten nebst allgemeinen Betrachtungen über Chromosomen, ......... Bibl. Gen. 8.

STow, I. (1927). A cytological study on pollen sterility in Solanum tuberosum L. Japan. Journ. Bot. 3.

SURFACE, F. M. (1916). Studies on out breeding. III. On the inheritance of certain glume characters in the cross Avena fatua $\times$ A. sativa var. Kherson. Genetics 1.

Theulung, A. (1928). Die Übergangsformen vom Wildhafertypus (Avenae Agrestes) zum Saathafertypus (Avenae Sativae). Recueil des Travaux Bot. Néerl. 25 A.

Trompson, W. P. (1926 a). Chromosome behavior in a cross between wheat and rye. Genetics 11.

_- (1926 b). Chromosome behaviour in triploid wheat hybrids. Journ. Gen. 17.

(1928). The genetics and cytology of a dwarf whaat. Trans. Royal. Soc. Oanada 5.

TrscHIER, G. (1928). Ü̉ber eigenartige Chromosomenbindung bei Ribes Gordonianum $(R$. sanguineum $\times$ R. aureum). Zeitschr. f. ind. Abst. u. Vererb. Supp. Bd. 2.

TrabUT, L. (1914). Origin of cultivated oat3. Journ. Hered. 5. (Translated in English by S. C. Stuntz.)

Tscrermar, E. von. (1914). Die Verwertung der Bastardierung für phylogenetisohe Fragen in der Getreidegruppe. Zeitschr. f. Pflanzenz. 2.

TÄCrвоLM, G. (1922). Zytologische Studien über die (trattung Rosa. Acta Horti Berg. 7.

VATILOV, N. I. (1914). Immunity to fungous diseases as a physiological test in genetics and systematics, exemplified in cereals. Journ. Gen. 4.

WAKAKUWA, SH. (1929). Variation of chromosome numbers among $F_{2}$ and $F_{3}-$ progenies in the crosses between dwarf wheats. Japan. Journ. Gen. 4. 
Watkrns, A. F. (1924). Genetic and cytological studies in wheat. I. Journ. Gen. 14. (1925). Genetic and cytological studies in wheat. II. Journ. Jen. 15.

WnNGE, Ö. (1924). Contributions to the knowledge of chromosome numbers in plants. La Cellule 35.

- (1924). Zytologisehe Untersuchungen über Speltoide und andere mutantenähnliche Aberranten beim Weizen. Hereditas 5 .

ZADE, A. (1914). Serologische Studien an Legminosen und Gramineen. Zeitschr. f. Pflanzenz. 2. (1918). Der Hafer. Gustav Fischer, Jena.

\section{Explanation of Plate I}

Fig. 1. A spikelet of Avena sterilis L. Empty glumes are removed.

Fig. 2. A. barbata PorT $\times$ A. sterilis $\mathrm{L}$.

Fig. 3. A. barbata Ротт

Fig. 4. A. barbata Ротт $\times$ A. fatua $\mathrm{L}$.

Fig. 5. A. fatua $\mathrm{I}$.

Fig. 6. A. fatua $\mathrm{\Gamma}, \times A$. sativa $\mathrm{\Gamma}$.

Fig. 7. A. sativa $\mathrm{L}$.

Fig. 8. A. sativa L. $\times$ A. byzantina C. КосH.

Fig. 9. A. byzantina $\mathrm{C}$. Косн.

Fig. 10. A. sterilis L. $\times$ A. byzantina C. KocH.

Fig. 11. A. strigosa ScrneB.

Fig. 12. A. barbata Potw $\times$ A. strigosa Schreb.

本諭文の要旨は日本遺傳學會第一回大會に於て報告せり。 (遗傳學雜誌第四卷第三號䔷照)。 
JAPANESE JOURNAL OF GENETICS, VOL, $V . \quad$ PLATE I

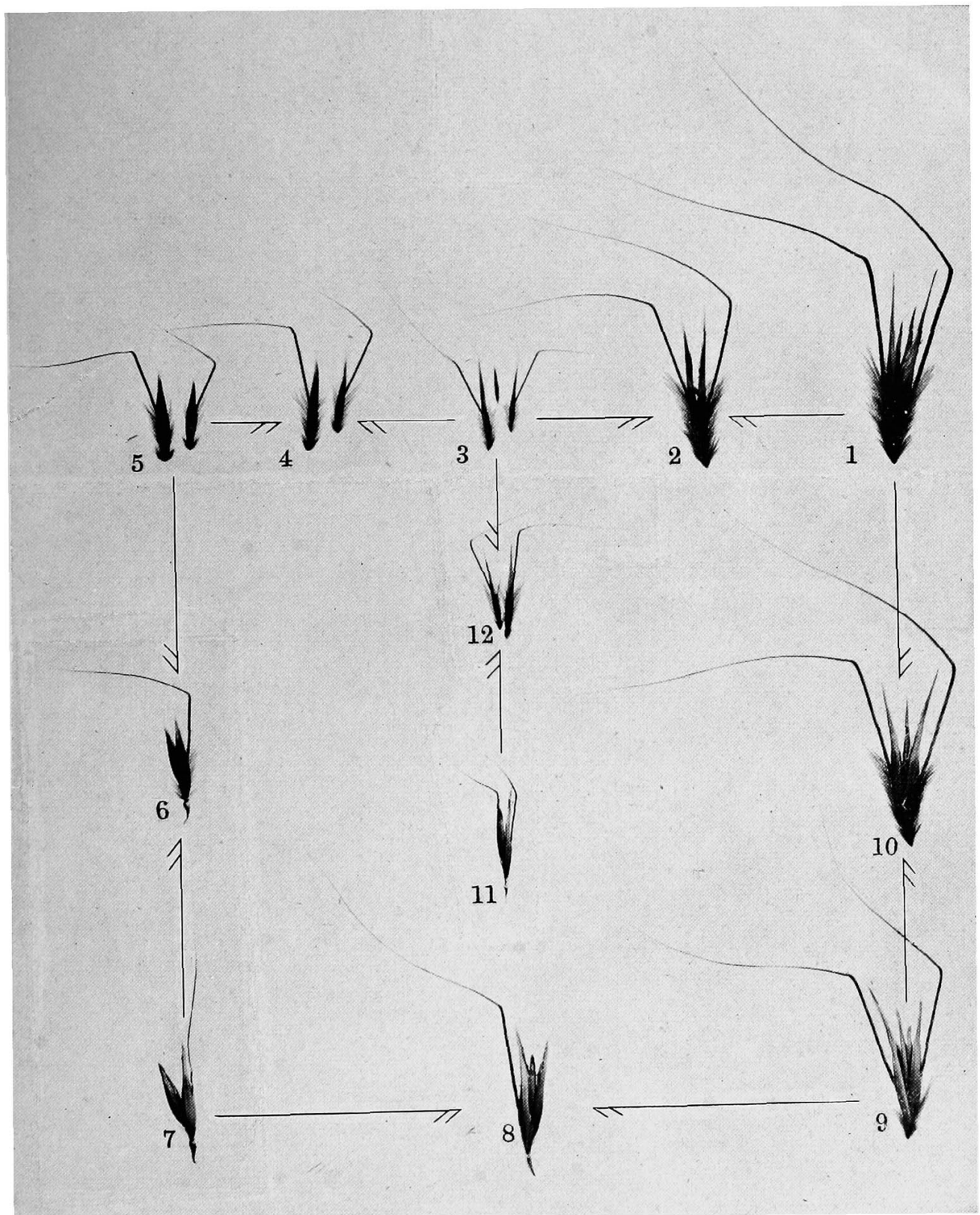

